\title{
The destabilisation of existing regimes: Confronting a multi-dimensional framework with a case study of the British coal industry (1913-1967)
}

\author{
Bruno Turnheim ${ }^{\mathrm{a}, *}$, Frank W. Geels ${ }^{\mathrm{b}}$ \\ a SPRU, University of Sussex, Brighton, UK \\ b Sustainable Consumption Institute, University of Manchester, UK
}

\section{A R T I C L E I N F O}

\section{Article history:}

Received 25 October 2010

Accepted 5 April 2013

Available online 17 September 2013

\section{Keywords:}

Regime destabilisation

Unlocking

Inter-disciplinary theorising

Coal industry

\begin{abstract}
A B S T R A C T
Because innovation studies are oriented towards novelty, scholars in this field have paid less attention to the destabilisation of existing regimes. This paper discusses four views on industry destabilisation and presents an encompassing conceptual framework, which addresses interactions between the build-up of external pressures, industry response strategies, and the gradual weakening of commitment to existing regime elements. We confront the framework with an in-depth longitudinal case study of the British coal industry (1913-1967). Specific conclusions are developed about different degrees of regime inertia, the ebb and flow of external pressures, the relative importance of economic and socio-political pressures, and interactions between them.
\end{abstract}

(C) 2013 Elsevier B.V. All rights reserved.

\section{Introduction}

This article addresses a neglected topic in the literature on technical change and innovation: the destabilisation of existing industry regimes. While the innovation studies literature has paid much attention to the emergence of novelty and the lock-in mechanisms that create stability and path dependence, less attention has been paid to the reverse topics of unlocking and the loss of stability. We will investigate the topic of destabilisation for well-established industries and propose a multi-dimensional framework.

To delineate the topic, we start with understandings of lockin and path dependence. To explain why incremental innovation proceeds along predictable (technical) trajectories, evolutionary economists (Nelson and Winter, 1982) proposed the notion of technological regimes to indicate that firms-in-industries are locked in by cognitive routines and technical knowledge. Neo-institutional theory also acknowledges the relative stability of industries, which it explains with concepts such as shared beliefs and industry mindsets (Phillips, 1994), regulatory institutions (Scott, 1995), and shared identities and missions. Both theories imply that firmsin-industries are constrained by existing templates (which we later call 'industry regimes'). These templates shape how firmsin-industries perceive threats and opportunities in environments,

\footnotetext{
* Corresponding author.

E-mail addresses: b.turnheim@sussex.ac.uk (B. Turnheim), frank.geels@mbs.ac.uk (F.W. Geels).
}

how they think about solutions, and what they see as appropriate action. While we know much about lock-in and stability, this paper addresses the question: how do how do existing templates (regimes) lose their grip on firms-in-industries?

This question has relevance for the broader debate on strategic reorientation of incumbent industries, which entails a shift from one industry regime to another. In terms of Lewin (1947), who conceptualised strategic change as a three phase-process of unfreezing-change-refreezing, our focus is on the process of 'unfreezing', which we conceptualise as ‘unlocking' or 'destabilisation' of an existing industry regime. The question also has relevance for the debate on socio-technical transitions (Geels, 2002; Geels and Schot, 2007), where most contributions focus on the emergence and diffusion of radical innovations. Shove and Walker (2007: 767) suggested that:

“A more comprehensively systemic approach (...) would also offer an equally detailed analysis of processes that parallels those of innovation, these being trajectories of erosion, decay, and fossilisation. (...). Transitions of any description routinely involve and require the loss or abandonment of previously important sociotechnical systems".

In response to this call, Turnheim and Geels (2012) developed an initial conceptual framework on regime destabilisation, which they illustrated with two brief case studies of the UK coal industry (1913-1967, 1967-1997). The present paper builds on but goes beyond Turnheim and Geels (2012) in several ways. Firstly, we provide a deeper literature review to better embed the conceptual 


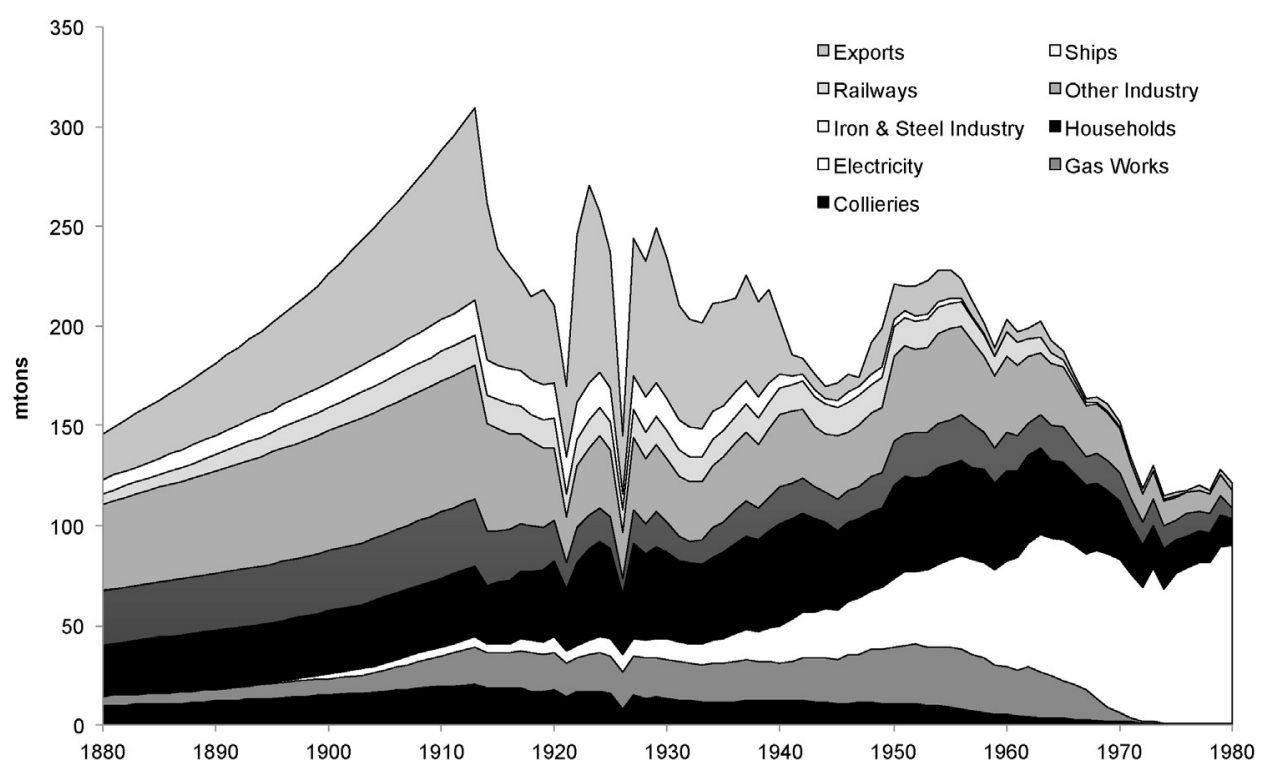

Fig. 1. British coal sales by sector (Data: Fouquet, 2008, DECC Historical data).

framework in the literature. Secondly, we extend the conceptual framework by further articulating interactions between three core processes (accumulation of external pressures, response strategies to performance problems, weakening commitment to regime elements). Thirdly, we articulate epistemological principles for indepth studies of industry destabilisation (temporal unfolding and process tracing, co-evolution and spillovers, narrative explanation). And, fourthly, as a methodological contribution we develop heuristic spillover figures for tracing interactions between external pressures.

Our conceptualisation of regime destabilisation builds on a triple embeddedness framework (Geels, 2013), which provides a multi-dimensional conceptualisation of incumbent industries. This framework is especially useful for large, politically powerful, and scale-intensive industries (e.g. oil, coal, automobiles, electric utilities, gas, agri-food). For these industries, regime destabilisation is likely to entail not only economic and technical processes, but also political and cultural processes. The conceptual model on regime destabilisation therefore distinguishes three core dimensions: (1) flow of financial resources from an external economic environment (markets, supply), (2) legitimacy and support from wider public and policymakers in an external socio-political environment), (3) endogenous commitment of firms-in-industries to the existing regime (trust, confidence). Our basic explanation is that destabilisation entails pressures from external environments (e.g. declining markets, eroding legitimacy), which create problems for firms-inindustries (e.g. financial losses, worsening reputation, decreasing support), which undermine their commitment to the existing industry regime. Early destabilisation implies actors formulating doubts and asking questions about the suitability of existing practices, technologies, beliefs, business models. Full destabilisation means that they lose faith in the existing industry regime and (want to) move to a new regime.

This initial discussion means that regime destabilisation is not the same as economic decline (shrinking markets, bankruptcies). Instead, we see economic decline as a contributor to destabilisation. But this contribution does not always have immediate effects. In fact, our case study will show that the British coal industry experienced economic decline for 40 years (1914-1946), but remained committed to core elements of the industry regime. The case study thus shows the strength of (some) lock-in mechanisms associated with deeply entrenched regimes.
We confront the conceptual framework with a longitudinal case study of the British coal industry (1913-1967), which is an exemplar of a large, socially embedded, and politically relevant industry. In 1913, coal was the single largest employer of industrial labour, providing jobs to $10 \%$ of the occupied male population (Dintenfass, 1992). Coal exports accounted for $10 \%$ of the total value of British exports. Coal was also used in many domains, e.g. households, factories, railways, steamships, iron and steel industries, gas works, electric power stations, and collieries.

Since World War I, the industry experienced a decades-long decline in overall markets (Fig. 1), which was halted by the postwar reconstruction boom. After the local peak in 1957, markets further declined, especially after the 1965 White Paper on Fuel Policy, which institutionalised the shift towards a four-fuel economy (coal, nuclear power, natural gas, oil).

Regime destabilisation is more complicated than declining markets. In the inter-war period, coal industry actors remained committed to the existing regime: (a) the perceived mission and identity was a supply-side oriented extraction industry (limitedly attentive to the demand side); (b) the core mindset was that Britain was built on coal and would remain so in the future; (c) technical operations were labour-intensive and craft-based. One regime element (technical operations and capabilities) was changed in the post-war mechanisation and modernisation programmes (implying destabilisation of previous routines and capabilities). Full destabilisation occurred in the late 1950s and early 1960s when declining markets, accumulating losses, and decreasing political support undermined the confidence of industry actors. Industry actors then abandoned existing mindsets, identity, business models, and technology, and shifted to a new industry regime.

The case study will further explore these dynamics and test the plausibility of the extended conceptual model. We bound the case study in 1967, because industry actors had by then lost confidence in the old industry regime and moved towards a new one. ${ }^{1}$

Section 2 briefly discusses insights from existing literatures and presents an integrative conceptual framework on regime destabilisation. Section 3 discusses epistemological assumptions,

\footnotetext{
1 Our analysis focuses on the aggregate industry. We acknowledge the regional diversity of the British coal industry, but can unfortunately not do justice to local variations because of space limitations.
} 


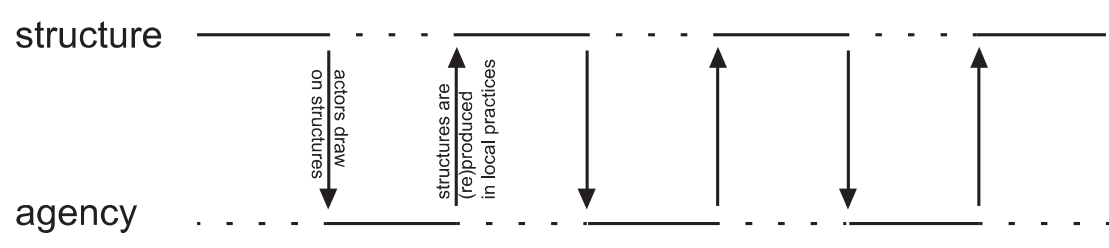

\section{time}

Fig. 2. Recursive relationship between agency and structure.

methodology, and data sources. Section 3 also discusses the usefulness of history, which is the topic of this special issue. Section 4 presents the case study. Section 5 analyses the match between the case and the conceptual perspective. The paper ends with conclusions.

\section{Conceptual framework}

\subsection{Discussion of existing literature}

To orient our research and generate conceptual building blocks, we discuss insights from four relevant literatures: industrial economics, evolutionary economics, neo-institutional theory, and management studies.

Industrial economics focuses on firms-in-industries, which face Porter's (1980) five industry forces related to suppliers, customers, new entrants, competitors, and technological alternatives. Firms aim to defend their position against these forces (through price competition, product positioning, advertising, R\&D, legal tactics, plant investment, merger and contracts). The main drivers for destabilisation are competitive and financial resource problems, which can come from shrinking markets, changing markets, or competition from new entrants or new technologies. In response to these problems, firms defend themselves through 'retrenchment strategies' (Barker and Mone, 1994), e.g. downsizing, cost-cutting, efficiency improvements, tighter controls. But they can also abandon existing positions or practices when it is no longer in their interest to reproduce them. Because industrial economics has a rational actor view, these 'positioning strategies' are seen as relatively unconstrained by routines or institutions.

Evolutionary economics assumes that actors are boundedly rational, perceiving firms as locked-in and constrained by standardoperating procedures, routines, capabilities and technological regimes (Nelson and Winter, 1982). Industry-competition is seen as innovation-based. Competitive and financial resource problems are seen as the main driver of destabilisation. When economic performance falls below aspiration levels, actors will engage in 'local search' that is compatible with existing technological regimes. This may result in incremental innovation or adjustment in routines and operating procedures. If performance problems continue, actors may engage in more 'distant search' and the exploration of radical alternatives (March, 1991). This implies weakening commitment to the existing technical regime and may eventually result in its abandonment.

Neo-institutional theory is concerned with the deeper and more resilient aspects of organisational structures. While firmsin-industries differ in some respects, they are similar in terms of deeper 'institutional logics' (Scott, 1995) - cultural beliefs, values and ideas shared by members of an organisational field. Destabilisation is therefore seen as a de-institutionalisation process in which actors abandon sector-specific institutions, especially shared beliefs and values. Neo-institutional theory (Scott, 1995) suggests that external pressure can come from an economic environment (which accommodates factors from industrial and evolutionary economics) and a socio-political environment, which contains policymakers, civil society, and social movements. External support from these socio-political stakeholders may weaken if industries lose political or cultural legitimacy (Oliver, 1992).

Neo-institutional theory also provides an internal explanation, which builds on Giddens's (1984) view that institutional structures (mindsets, mission, values) are continuously enacted and reproduced. This recursive relationship in ongoing processes is schematised in Fig. 2: actors draw on existing structures for action, and structures are (re)produced in local practices.

The internal enactment of destabilisation thus implies weakening re-production of institutional logics. Actors lose commitment and 'break away' from established patterns by questioning inherited institutions (de-institutionalisation) while simultaneously producing new ones (re-institutionalisation) (Fig. 3). The questioning of institutional logics is difficult because it concerns destabilising the 'normality' of taken-for-granted practices and assumptions (Giddens, 1984).

4. The managerial literature on organisational decline proposes phase-models that contain elements from the three theories discussed above. Weitzel and Jonsson (1989) distinguish five phases, while other scholars distinguish three or four (Hambrick and D'Aveni, 1988; Collins, 2009). In early stages, a common problem is that firms-in-industries do not perceive or misinterpret structural problems (Barr et al., 1992). When decline becomes noticeable, firms may employ the retrenchment strategies or incremental innovation strategies, discussed above. If performance problems continue, commitment to existing technologies may weaken as actors engage in more distant search, exploring radical alternatives. Strategic reorientation to new technologies is risky and therefore often prompted by shocks: "It often requires a crisis to stimulate new initiatives, and to persuade boards of directors to take radical measures and to accept new approaches which they would not normally be prepared to consider" (Taylor, 1982: 13). Tushman and Romanelli (1985) distinguish 'strategic reorientation', which entails changes in technology and markets, from more comprehensive 'strategic recreation', which additionally entails changes in core beliefs and. Strategic recreation thus entails the destabilisation of institutional logics and second-order learning (Argyris, 1976) in which actors question core beliefs, identities, and business models. If strategic reorientation/recreation halts further decline, destabilisation will have occurred by shifting to a new regime; if decline continues, organisations may dissolve, which also results in actors abandoning old regimes.

Our interpretation of the organisational decline literature thus suggests that the first three theories can be seen as complementary, referring to different phases and degrees of destabilisation. Fig. 4 provides a schematic summary, showing that actors gradually question more foundational regime elements as doubts grow and commitment weakens.

The literatures discussed above provide useful insights for understanding regime destabilisation. Several points need further elaboration, however, such as the role of legitimacy and socio-political environments; the different elements of industry 


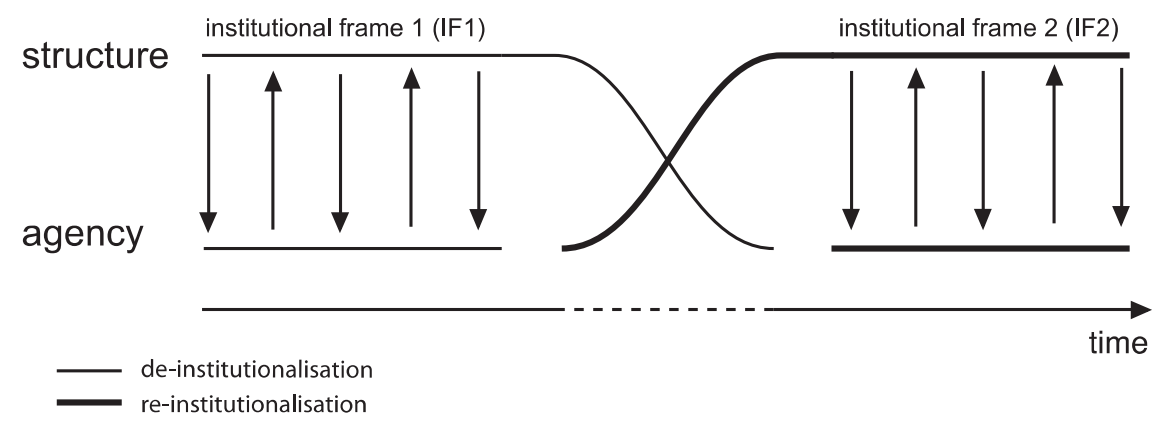

Fig. 3. De-institutionalisation and re-institutionalisation in destabilisation processes (drawing on Den Hond and De Bakker, 2007; Giddens, 1984).

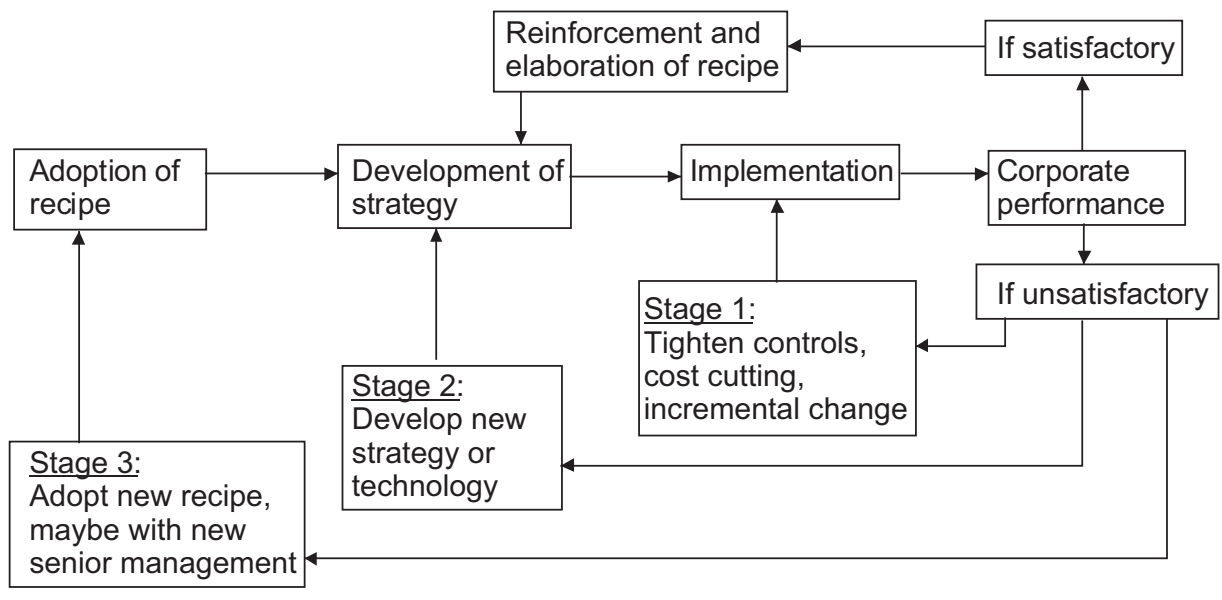

Fig. 4. Dynamics of reorientation (Grinyer and Spender, 1979:122) $)^{14}$.

regimes; and the positioning of different views in an encompassing framework. To address these issues, Section 2.2 first discusses an integrative triple embeddedness framework of industries. Section 2.3 then conceptualises regime destabilisation as a multi-dimensional and enacted process.

\subsection{Conceptualising incumbent industries with a triple embeddedness framework}

The triple embeddedness framework (TEF) is a new conceptual model, which provides a broader understanding of industries (Geels, 2013). The TEF sees industries as populations of firms embedded in an organisational field, which consists of "critical exchange partners (suppliers, customers), sources of funding, regulatory groups, professional and trade associations, special interest groups, the general public" (Hoffman, 2001: 136). Building on institutional theory, the TEF divides the organisational field into two environments with different selection pressures.

The economic environment includes actors engaged in economic transactions. Firms-in-an-industry face Porter's (1980) competitive forces. They face economic selection pressures and compete on price and performance dimensions.

The socio-political environment contains policymakers, civil society, and social movements. Organisations compete for social fitness and legitimacy. Selection pressure arises from formal institutions (policies, regulations) and informal institutions (public values, expectations). Social fitness and legitimacy derive from adherence of industries to these institutions (Scott, 1995).

14 Grinyer and Spender (1979:116) define 'industry recipe' as 'the industry's pattern of managerial beliefs".
The TEF also sees industry actors as structurated by an 'industry regime' - a set of industry-specific institutions that provide collective templates. Geels (2013) distinguishes four core regime elements: (1) mindsets, cognitive frames, (2) identity, norms, mission, (3) capabilities, technical knowledge, (4) formal-regulatory institutions (regulations, taxes, subsidies). Using terminology from Scott et al. (2000), the first three elements are 'institutional logics': the normative and cognitive constructions that constitute endogenous organising principles. The regulatory element is part of a 'governance system', which is partly externally imposed (by policymakers) and partly enacted via compliance mechanisms. Fig. 5 schematically represents the triple embeddedness framework.

The regime elements make up semi-coherent configurations that give industries orientation and directionality. Industry actors are committed to existing industry regimes, which are stabilised by various lock-in mechanisms (Turnheim, 2012):

1) Shared mindsets and belief systems can contribute to cognitive inertia, blinding actors to developments outside their focus.

2) Industry mission and identity refer to taken-for-granted beliefs that actors have about themselves and their role in society.

3) Technical knowledge and competencies form resources for operational processes and innovation, representing 'cognitive capital' that constrains what actors can do.

4) Regulatory institutions provide incentives that facilitate actions in certain directions rather than in other directions.

Because of these lock-in mechanisms, firms-in-an-industry have preferences for incremental change within the parameters of the existing industry regime. The bidirectional arrows in Fig. 5 indicate that industry actors are not only influenced by external 


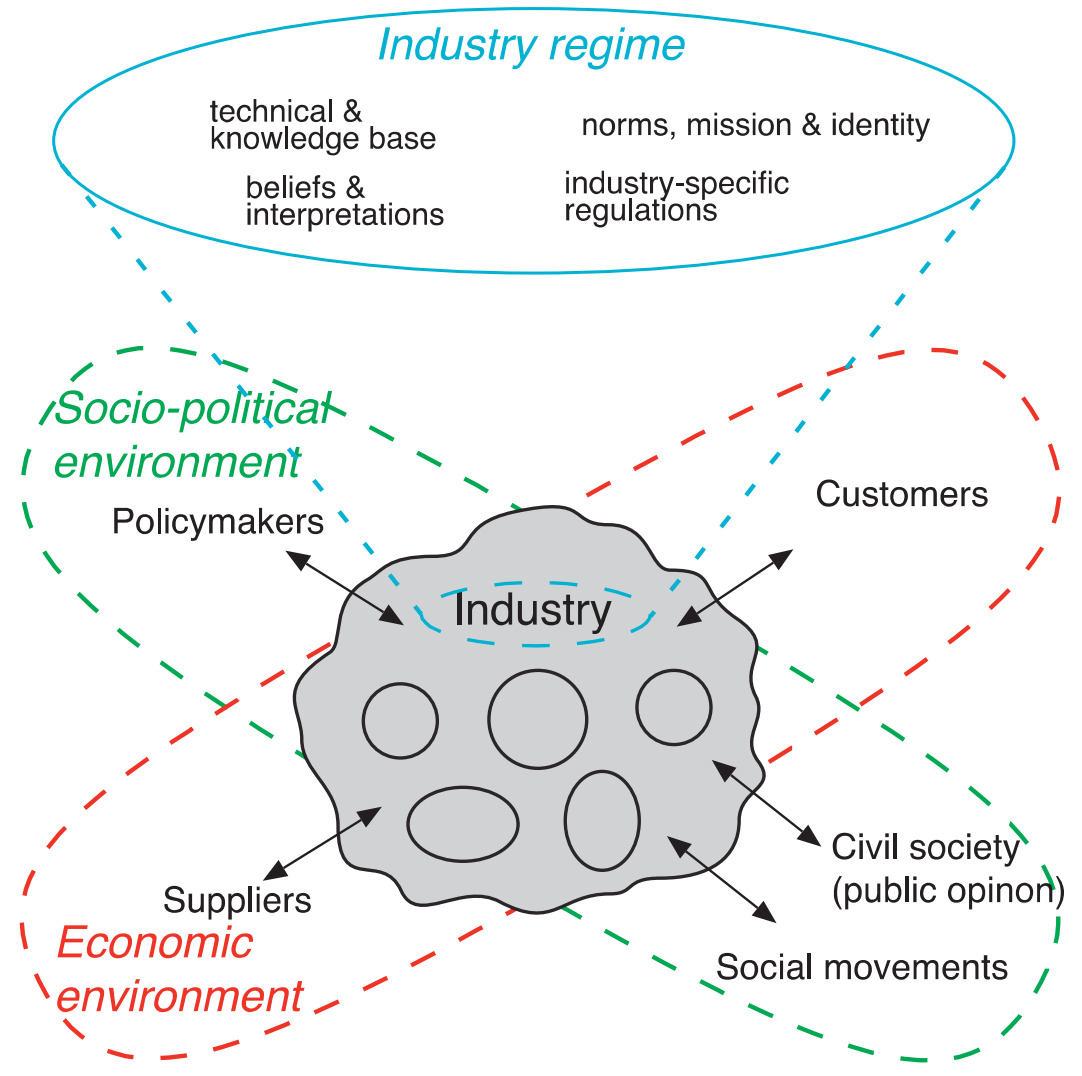

Fig. 5. Triple embeddedness framework (TEF) of industries (Geels, 2013).

pressures, but also respond strategically to their environments within the bounds of industry regimes. The main strategies towards various environments are: economic positioning strategies, innovation/technology strategies, political strategies, and socio-cultural strategies (Turnheim and Geels, 2012).

The TEF is a multi-dimensional framework of industries that includes broader environments and types of agency than existing approaches. $^{2}$

\footnotetext{
2 The TEF has similarities to evolutionary economics (EE): industry actors adapt to pressures from selection environments and adaptive responses are constrained by regimes (Nelson and Winter, 1982). But it is broader in several respects. First, it includes political and socio-cultural environments, which are under-developed in EE. Second, 'industry regimes' are broader than 'technological regimes' (routines, technical capabilities), and also include mindsets, mission and identity. Third, agency in the TEF includes not only R\&D investment and (technical) search activities, but also a range of strategies.he TEF accommodates Porter's (1980) five industry forces in the economic environment, but adds pressures in the socio-political environment. While Porter (1980) uses a rational choice conceptualization of actors, TEF has a broader view of agency.The TEF has similarities to institutional economics as it recognises the importance of 'rules of the game' (North, 1990). Whereas institutional economists tend to give more attention to formal rules (property rights, contracts, patent laws, tax structures), the TEF acknowledges formal-regulatory, normative, and cultural-cognitive institutions. Another difference is that institutional economists (Olson, 1965; North, 1990) adopt a rational choice view of actors, whereas the TEF is based on other ontological assumptions.The TEF also has some similarities to population ecology (Hannan and Freeman, 1989), because both approaches (a) see industries as populations of firms operating in an economic and socio-political environment, (b) highlight organisational inertia, (c) use the concept of legitimacy. But, building on criticisms of population ecology (Zucker, 1989; Baum and Powell, 1995), there are also differences: (a) population ecology has no agency (except entry and exit), because firms remain inert once they are formed; TEF, in contrast, accommodates many types of agency (and allows for qualitative transformation), (b) population ecology conceptualises legitimacy via density dependence (legitimacy increases with the number of organisations in a
}

\subsection{Conceptualising the destabilisation of industry regimes}

Using the TEF, we can now more precisely define industry destabilisation as a discontinuation of the reproduction of core elements of the industry regime. Building in Section 2.1, we suggest that destabilisation of industry regimes entails interactions between three processes:

1) The accumulation of external pressures on industries. In the economic environment, pressures can come from shrinking markets, changing markets, supply problems, or competition from new entrants or new technologies. In the socio-political environment, pressures can come from changes in policy, public opinion, cultural discourse, or social movement protests. These external pressures may negatively affect financial resource flows (that enable industry actors to reproduce core regime elements) or legitimacy (which affects public and political support for industries).

2) Performance problems (financial or legitimacy) trigger responses from industry actors, which modulate pressures from external environments.

3) If external pressures and performance problems continue, commitment of industry actors to established industry regimes may gradually weaken. Because of lock-in mechanisms, actors will initially defend existing regime elements. Building on our discussion of the organisational decline literature, commitment weakens gradually through several phases: (a) initial

population); TEF sees legitimacy as arising from conformity to cognitive, normative and regulatory institutions, (c) population ecology sees the state as the main dimension of the socio-political environment; TEF also pays no attention to civil society, social movements, and wider publics. 
retrenchment (cost cutting, tighter control), (b) local search and incremental innovation, (c) more distant search and exploration of technical alternatives (March, 1991), (d) questioning of core beliefs, mission and business models (Barr et al., 1992). The third phase signals early destabilisation ('unlocking' of technical and governance regime elements), and the fourth phase full destabilisation (additional 'unlocking' of belief systems, mission, identity, business models). The associated processes of strategic 'reorientation' or 'recreation' are often stimulated by crises (major financial losses, loss of legitimacy and support). Strategic reorientation/recreation may lead to successful turn-around (and a shift to a new industry regime). But extreme or vacillating actions (e.g. crash programmes, excessive risk taking) can also exacerbate problems (Hambrick and D'Aveni, 1988). Alternatively, strategic responses may be 'too little, too late', in which case the industry enters 'endgame' strategies (Harrigan, 1980) such as early exit or milking the assets.

We will explore the plausibility of this framework with a longitudinal case study. This study will also investigate the following specific questions:

a) Are some regime elements harder to change than others?

b) Do pressures increase linearly in one direction (as assumed in the above discussion of phases)? Or can pressures also weaken, thus potentially halting destabilisation processes?

c) What is the relative importance of pressures in the economic and socio-political environment?

d) Is destabilisation caused by single pressures or multiple pressures? Are external pressures independent of each other (as the question on relative importance assumes)? Or do they interact and influence each other?

\section{Epistemology, methodology and data sources}

In our view, the 'usefulness' of history goes far beyond a dataset for the testing of hypotheses or history-friendly models. Instead, we suggest that historians practice a particular kind of explanation that has much to offer to innovation studies, particularly for understanding long-term change processes such as destabilisation and transitions (see also Von Tunzelmann, 1978). We distinguish three specific characteristics and mobilise reflections from historians and historical sociologists about historical explanation. We then describe the case study methodology.

\subsection{Temporal unfolding and process tracing}

Sewell (2005: 6-7) suggests that historians know "how to think about the temporalities of social life. The common topic of historians is the unfolding of human action through time. (...) Every act is part of a sequence of actions and its effects are profoundly dependent upon its place in the sequence." Historians understand processes as sequences of events. This kind of 'process tracing' takes path dependence seriously and goes 'inside the black box' to explain how actions and changing contexts produce event chains. Processes may unfold at different levels and follow different temporalities:

"One significant characteristic of historical events is that they always combine social processes with very different temporalities - relatively gradual or long-run social trends, more volatile swings of public opinion, punctual accidental happenings, medium-run political strategies, sudden individual decisions, oscillating economic or climate rhythms - which are brought together in specific ways, at specific places and times, in a particular sequence" (Sewell, 2005: 9).

\subsection{Multiple causes, co-evolution, spillovers and lateral thinking}

Historians assume that the world is complex and multidimensional (Von Tunzelmann, 1978). Explanations therefore often entail conjunctures between multiple processes:

"Most historical sociologists reject the notion of a single master process, acknowledging multiple processes that overlap and intersect one another. Explaining a particular outcome or pattern of development thus involves a particular logic of explanation: situating events or outcomes in terms of their location in intersecting trajectories with independent temporalities" (Aminzade, 1992: 466).

Events are seen as being over-determined and having multiple causes:

"Most historians will go to some lengths to avoid a 'monocausal explanation'. Almost all historians are used to the idea that historical events are frequently over-determined, that is they may have several sufficient as well as necessary causes, any one of which might have been enough to trigger the event on its own" (Evans, 2000: 158).

Historians also distinguish different kinds of causes. Gaddis (2002), for instance, suggests that historians provide layered explanations that incorporate immediate causes (actions, decisions, trigger events), intermediate causes (social contexts, specific discourses, actors dependencies) and distant causes (broader contexts such as macro-ideologies, wars, economic cycles). Furthermore, historians pay attention to multi-dimensional spillovers and coevolution:

"Specialist expertise (...) compartmentalizes human experience into boxes marked 'economics', 'social policy' and so on, each with its own technical lore, whereas what is really required is an openness to the way in which human experience constantly breaks out of these categories. These lateral links with different aspects of society are much easier to discern with the benefit of hindsight. (...) Historians can claim with some justice to be specialists in lateral thinking" (Tosh, 2010: 37).

\subsection{Narrative explanation}

To accommodate process tracing, co-evolution and spillovers, historians often use the epistemological style of 'narrative explanation'. Narratives are strong in capturing complex interactions between agency and changing contexts, time, event sequences, making moves in games.

"Theorizing the social process via narrative is a deep tradition in both history and sociology. If there is any one idea central to historical ways of thinking, it is that the order of things makes a difference, that reality occurs not as time-bounded snapshots within which "causes" affect one another (...), but as stories, cascades of events" (Abbott, 2001: 227).

"Narrative explanation takes the form of an unfolding, openended story fraught with conjunctures and contingency, where what happens, an action, in fact happens because of its order and position in the story. Narrative therefore permits a form of sequential causation that allows for twisting, varied, and heterogeneous time paths to a particular outcome" (Griffin, 1993: 1099).

Not all narratives can be seen as process theories, however. Some narratives only describe 'one damn thing after another'. To develop causal narratives, explanations therefore need be guided by conceptual themes or frameworks. Theories tend to be embedded 
within narratives (Gaddis, 2002), so "theory for historians usually means the framework of interpretation that gives impetus to an enquiry" (Tosh, 2010: 214). But historians rarely perform formal tests of theories. Instead, they judge theories and conceptual frameworks for their usefulness in writing plausible and interesting narratives. That is also what we aim to do in this paper.

To explore the plausibility of our conceptual framework, we confront it with a longitudinal case study of the British coal industry (1913-1967). We adopt a case study strategy, because case studies are well suited for exploratory research, rich in context and enable 'process tracing' of event chains. The aim is not to tell a comprehensive story 'as it really was', but to provide a more selective analytical narrative which is guided by the conceptual categories.

The case study draws on secondary and primary sources. Secondary sources have highlighted economic, technical, and sociopolitical dimensions (Buxton, 1970; Ashby and Anderson, 1981; Ashworth, 1986; Church, 1986; Supple, 1987, 1988; Dintenfass, 1992; Thorsheim, 2006). As primary sources, we used newspaper articles in The Times to gather information about public opinion and discourse. We used government committee reports and White Papers to investigate political and regulatory dimensions. To gather industry-internal information, we used the memoirs of Robens (1972), the NCB chairman between 1961 and 1971, and annual reports from the National Coal Board (after 1946). ${ }^{3}$ Although both sources should not be taken at face value, they provide interesting data for discourse analyses that trace gradual changes in beliefs and orientations. This variety in data sources enables triangulation, and allows for a rich analysis of various contexts and response strategies.

To divide the longitudinal case into periods, we used the following changes in the external environments with lasting effects: 1913 (local coal consumption peak), 1930 (Great Depression), 1946 (nationalisation of the coal industry), 1956 (Clean Air Act). For each period, the analytical narrative traces the tree main concepts of our model: external pressures in economic and sociopolitical environments, strategic responses, and commitment to the existing industry regime. It was not always possible to maintain chronology because this analytical structure separates pressures and responses.

For each period, we also make an interpretive summary of the relative size and spillovers of external pressures in a multidimensional space. The schematic figures are based on the TEF (Fig. 5), with the exception that the industry regime has been left out (because the figures focus on pressures rather than responses). The grey surface area in these figures represents the coal industry (with a rough indication of its size, pressures impinging on its shape, and protective measures as a thickening of its boundaries). Pressures are represented by arrows directed at the industry (thickness roughly indicating intensity). Spillovers are represented by arrows between pressures. Pressure alignment is indicated by their joint directionality towards the industry. Broader secular trends are represented outside industry environments. We use these analytical representations as an interpretive heuristic in tracing multi-dimensional interactions between pressures in the TEF's economic and socio-political environments. The symbolic representations emanate from our interpretive weighting of pressures and their interactions, and their positioning in the multidimensional space.

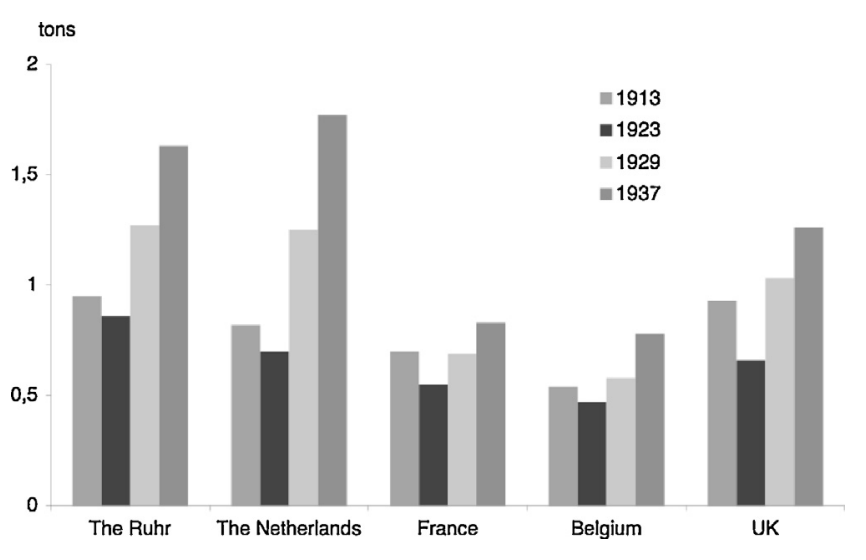

Fig. 6. Output per manshift (kg) (based on data from Scott, 2006).

\section{The destabilisation of the British coal industry (1913-1967)}

\subsection{Early problems (1913-1930)}

\subsubsection{Pressures in economic and socio-political environment}

Markets: Between 1850 and 1913, markets grew around 4\% per year (Church, 1986). World War I disrupted export markets, which in 1913 accounted for about 30\% of total sales (Fig. 1). Export markets recovered in the early 1920s, were disrupted by the 1926 strike, and decreased throughout the late 1920s and 1930s. Most domestic markets (households, iron/steel industry, other industries, railways) fluctuated or stagnated after the war (because of price volatility or industrial fuel efficiency improvements). ${ }^{4}$ Gas and electricity markets grew. Collieries and shipping decreased, with the gradual introduction of more efficient diesel engines. Aggregate domestic demand grew only 0.7\% between 1913 and 1929 (Supple, 1988).

New entrants: British firms were losing export markets to intensified foreign competition, because foreign countries (like Germany and the Netherlands) expanded their own coal industries using the latest mining methods, which substantially improved productivity (Fig. 6).

Labour relations: Between 1881 and 1913 nominal wages in coal mining increased by $86.8 \%$, faster than in any other sector. These wage rises were not only linked to union activism, but also to strong market demand and rising coal prices (Boyer, 2004). Average wages increased substantially during the war (about $170 \%$ according to Ramsbottom, 1935). After the war, labour unions (unsuccessfully) lobbied for nationalisation. In 1919, mine-owners halved wages in 1920, which strained labour relations (Ramsbottom, 1935). New proposals for lower wages and longer working days led to major strikes in 1921 and 1924. Unions won these fights and achieved wage increases of about $8 \%$ in that period (Fig. 10). In 1925 proposals for wage reduction renewed tensions and culminated in the 1926 General Strike, which caused major market disruptions (Fig. 1). Mine owners defeated the unions and subsequently implemented major wage reductions (Court, 1945).

Technical alternatives: Coal gas and electricity were two new energy carriers, which on the one hand competed with the direct use of coal. On the other hand, they used coal as feedstock and thus formed growth markets. When electricity challenged gas in lighting markets, gas industry actors shifted their attention to domestic cooking and heating. Between 1882 and 1912, the number of

\footnotetext{
${ }^{3}$ All references to NCB documents are to Annual Reports if not stated otherwise, dated by the year of coverage.
}

${ }^{4}$ Between 1920 and 1935, electricity generation and iron production experienced fuel efficiency improvements of about 55\% and 40\% respectively (Buxton, 1979). 


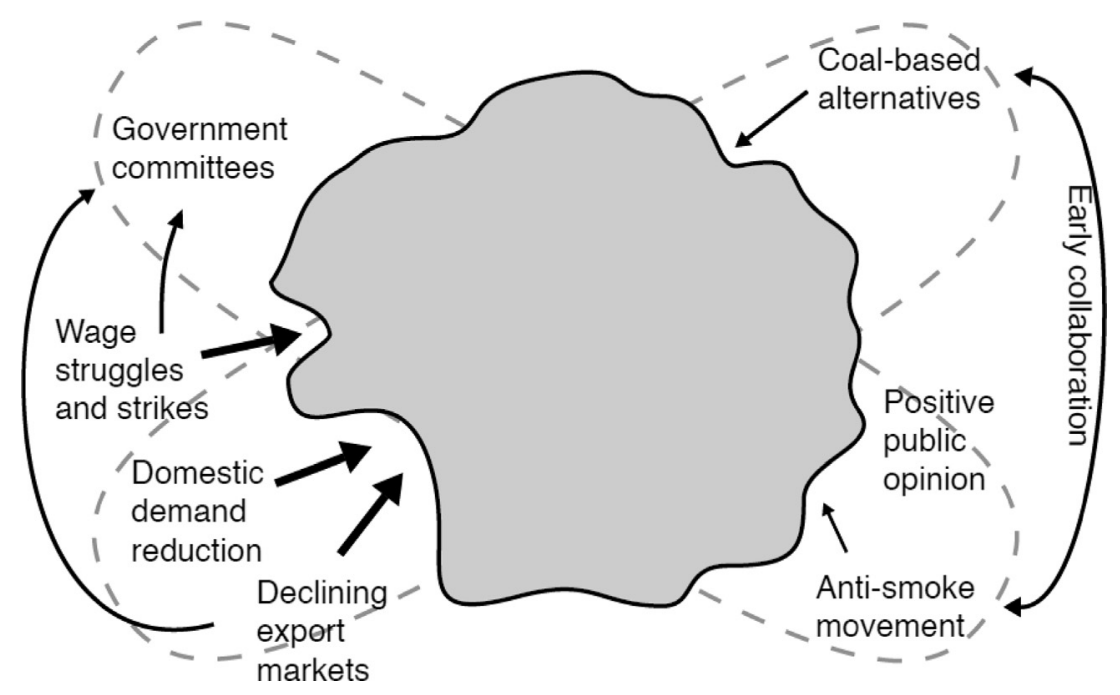

Fig. 7. Multi-dimensional pressures and spillovers (1913-1930).

gas consumers increased from 1,972,000 to 6,876,000 (Barty-King, 1984).

After the war, the production and consumption of gas accelerated (Table 1), because of scale effects, price decreases and distribution innovations (penny-in-the-slot metres). Electricity was increasingly used for lighting and powering machine-tools. Fuel efficiency improved as industries shifted from steam towards electric motors.

Fuel oil gained some early footholds in shipping and heavy industries. In 1913, for instance, the Admiralty shifted towards oil-burning vessels (Church, 1986).

Social movement and activism: Omnipresent coal use created smoke. Smoke abatement organisations, emerging in the 1880 s, framed smoke as a 'dangerous killer', responsible for respiratory diseases, deaths and general pollution. They tried to educate the public and lobbied for stronger smoke-regulations and greater enforcement of existing laws (Thorsheim, 2006). In the 1910s and 1920 s, professional groups (doctors, chemists, architects, engineers) joined the anti-smoke coalition, shifting the emphasis from behavioural change to technological solutions. Smoke reduction was reframed in terms of (fuel) efficiency and win-win solutions, because industries could simultaneously reduce fuel costs and diminish smoke problems (Stradling and Thorsheim, 1999). The expansion and professionalisation of the anti-smoke movement enhanced its credibility with policymakers. The gas industry also supported smoke abatement groups, and contrasted itself with coal as a clean, convenient, and smokeless alternative (Turnheim and Geels, 2012).

Public opinion: Smoking chimneys meant jobs and economic prosperity - the price to pay for progress (Church, 1986). Smoke activists were thus limitedly successful in influencing public opinion. In 1921 (23 August) a Times editorial commented that "We are still far from the point at which compulsion [of domestic smoke

Table 1

UK Gas production (million cubic feet) (Data: Williams (1981: 289)).

\begin{tabular}{lc}
\hline Year & UK gas production $(\mathrm{Mft} 3)$ \\
\hline 1887 & 56241 \\
1902 & 91956 \\
1912 & 126002 \\
1920 & 295857 \\
1930 & 313046 \\
1937 & 341985 \\
1946 & 446124 \\
\hline
\end{tabular}

curbing] is possible. Public opinion has to be educated" (cited in Thorsheim, 2006: 52).

Policy: The government was concerned about the industry's economic problems and, in 1925 and 1926, provided £23 million of direct subsidies (Allen, 1970). Expert committees were formed to investigate economic problems. The 1921 Sankey Commission concluded that the coal industry had too many suboptimal production units. The 1926 Samuel Commission reached a similar conclusion and promoted the amalgamation of smaller mines. The industry did not implement these recommendations, spurring political "disillusionment with the ability of the coal industry to govern itself" (Supple, 1988: 580). In the late 1920s, this frustration led to policy discussions of compulsory amalgamations, cooperative marketing schemes, and government-backed export cartels (Supple, 1988).

Policymakers gradually engaged with the smoke debate and released funding for coal smoke research (Thorsheim, 2006) and fuel efficiency. They did not introduce smoke regulations for households because homes were considered people's castles (Ashby and Anderson, 1981). The Newton Committee Report (1921) signalled increasing domestic smoke emissions, and recommended actions against commercial and domestic chimneys. Nevertheless, the subsequent Public Health (Smoke Abatement) Act (1926) was relatively weak, applied only to commercial installations, contained exemptions, and entailed insignificant fines (Ashby and Anderson, 1981).

Summary: Fig. 7 schematically summarises the main external pressures and spillovers.

\subsubsection{Industry response strategies}

Economic positioning strategies: In this period, the industry was squeezed between: (a) pressures from foreign industries in export markets, (b) high labour costs that consumed a large part of net proceeds, and (c) declining markets that caused over-supply, which in turn led to a substantial decrease in prices from WWI throughout the 1920s (Fig. 8; Buxton, 1979). These economic problems, exacerbated by miner strikes, led to mine closures, bankruptcies (Table 2).

The industry's primary response strategy was to reduce labour costs (Allen, 1970). Recommendations from policy committees (to amalgamate the thousands of undertakings into larger ones) did not lead to targeted responses because of limited industry coordination (Supple, 1987).

Innovation strategies: Coalface operations were labourintensive, relying on picks, sledgehammers and shovels (Court, 


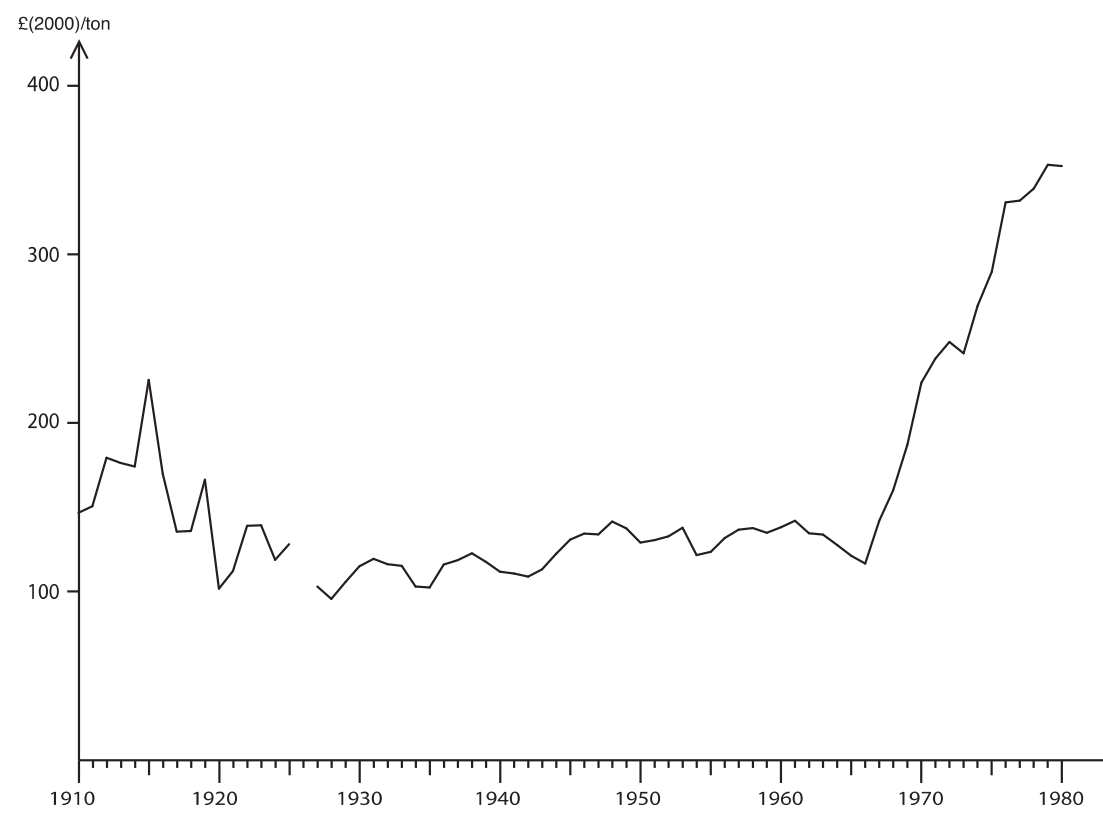

Fig. 8. Coal price ( $£ /$ tons), real at 2000 prices, using GDP Deflator (Data from Fouquet, 2008).

Table 2

Number of undertakings and mines (based on Allen, 1970; Court, 1945; Department of Trade and Industry, 2001).

\begin{tabular}{llr}
\hline & Undertakings/companies & Mines \\
\hline 1913 & & 3000 \\
1924 & 1400 & 2480 \\
1944 & 740 & 1630 \\
1948 & National Coal Board & 980 \\
1956 & National Coal Board & 850 \\
\hline
\end{tabular}

1945). Ponies or rope-systems transported coal to vertical shafts, where it was moved to the surface. Innovation strategies were not vigorously pursued. Already in 1903 a mine inspector complained that: "There is a sort of vis inertiae that you have to overcome at a great many collieries before you can get any new system introduced" (reported in Pollard, 1989: 27). WWI starved the mines of equipment, lowering production efficiencies and outputs. Post-war diffusion of coal-cutting machines and pneumatic picks was slow in Britain compared to other countries (Fig. 9).

Mechanical conveyors and power-loaders diffused more slowly. Technical innovation thus remained sparse and partial (Church, 1986). This also applied to the processing, washing, and grading

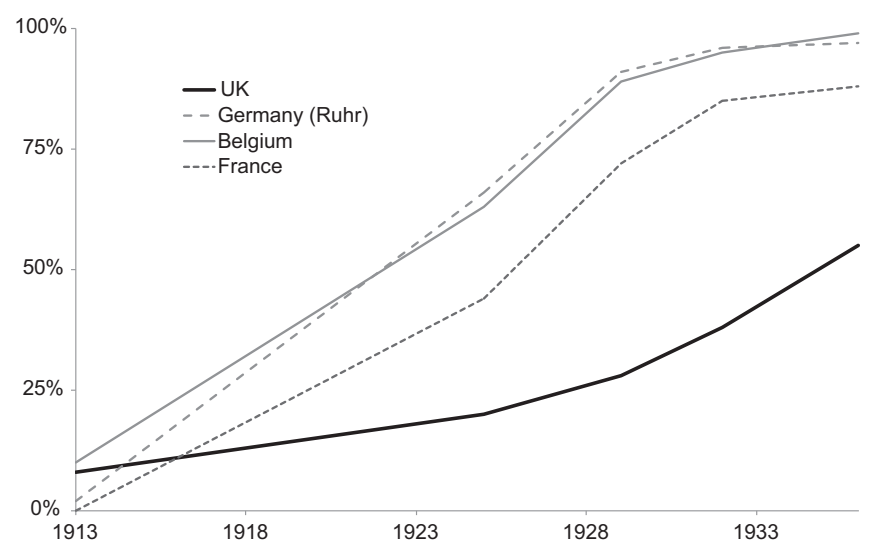

Fig. 9. Percentage of coal output mechanically cut in selected countries (Data: Buxton, 1979). of coal: "British companies (...) certainly did not set the pace in adopting sophisticated coal-processing techniques and marketing practices" (Dintenfass, 1992: 171).

Between 1913 and 1938, relative British productivity increases were slow compared to countries like Germany and the Netherlands, but respectable compared to countries like France and Belgium (Fig. 6). Average British productivity increases were held back by high regional disparities. In (many) old mines, improvements were slow because of thin coal seams, long and winding tunnels, greater underground haulage requirements, and smaller proportions of the workforce being employed at the coalface. In newer fields (e.g. North Midlands, Durham) improvements were more substantial and sometimes on par with best foreign mines (Greasley, 1990).

Some coal manufacturers began diversifying into (natural or synthetic) smokeless fuels (anthracite, briquettes, etc.), which were more expensive than bituminous coal and harder to ignite (Court, 1945).

Political strategies: After the war, the coal industry and the newly created Mineowners Association of Great Britain (MAGB) successfully lobbied against nationalisation proposals. Factoryowners lobbied city councils and judges to weaken the application

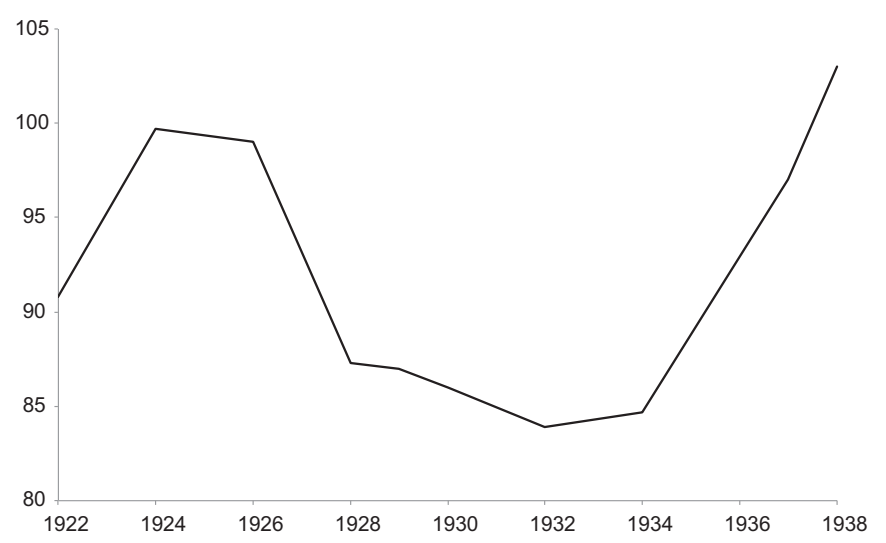

Fig. 10. Index number of wage rates for UK mining (1924=100) (Data: Ramsbottom, 1935). 


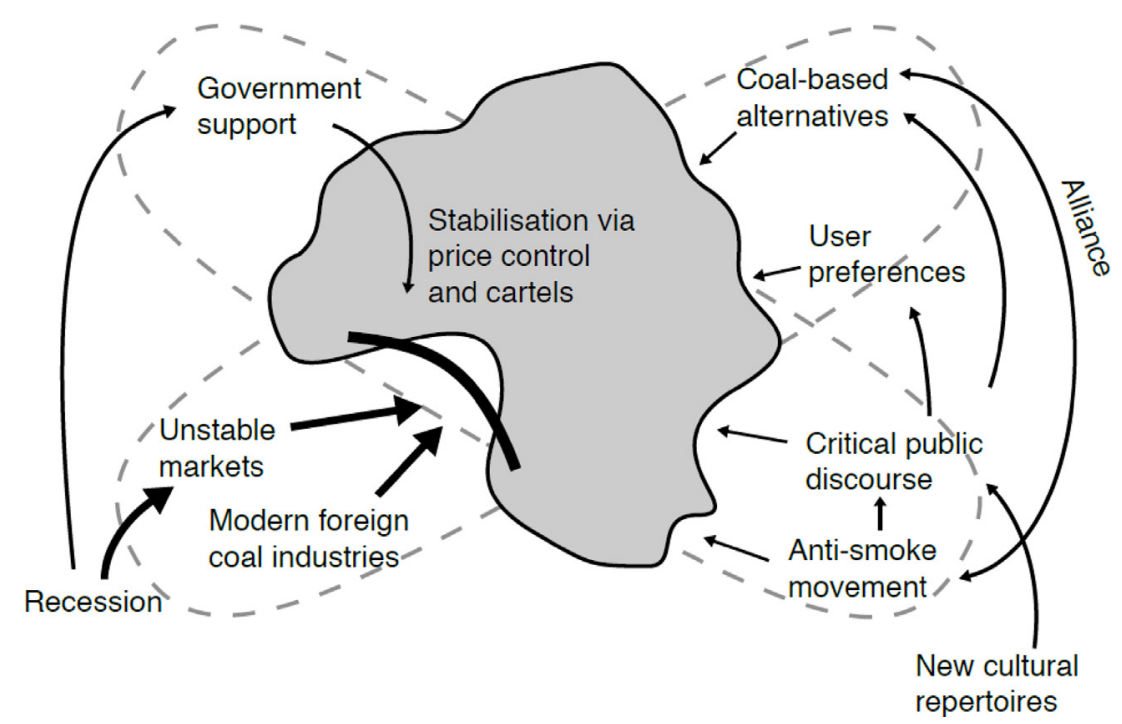

Fig. 11. Multi-dimensional pressures and spillovers (1930-1946).

of smoke-regulations (Stradling and Thorsheim, 1999). The Federation of British Industries (FBI) influenced the Newton Committee Report (1921) and succeeded in watering-down the Public Health Act (1926), "rendering the bill as innocuous as possible for business generally" (Sheail, 1997: 27-28).

Framing strategies: The coal industry downplayed the smoke problem, arguing that jobs and economic welfare were more important. The FBI also warned that smoke regulations would undermine competitiveness and lead to unemployment (Sheail, 1997).

\subsubsection{Regime commitment}

The industry regime remained stable. Major economic problems caused economic turbulence (bankruptcies, mine closures), but did not lead to substantial changes in the institutional logics or governance system. The industry implemented some incremental changes (coal cutters) that stayed within the bounds of the existing regime. Recommendations from government committees about the need for coordinated amalgamation and modernisation were not implemented. The industry downplayed smoke problems with political and framing strategies.

\subsection{Increasing pressures and piecemeal responses (1930-1946)}

\subsubsection{Pressures in economic and socio-political environment}

Markets: Household and industrial coal markets contracted during the Great Depression, picked up in the mid-1930s, and contracted again during World War II (Fig. 1). Export markets decreased continuously in the 1930s and collapsed during WWII. Collieries and shipping markets also decreased, the latter because of shifts to liquid fuels. These fluctuations caused bankruptcies and closures (Table 2) in what came to be seen as a 'sick industry' (Supple, 1988).

Technical alternatives: Fuel oil and diesel began to compete in heavy industries and railways, but did not diminish coal use besides in shipping. Electricity use in industry increased from $5000 \mathrm{GWh}$ in 1930 to $19,000 \mathrm{GWh}$ in $1948 . .^{5}$ In households gas and electricity increasingly competed with the direct use of coal (for lighting, cooking, heating and powering new appliances). ${ }^{6}$ But electricity

\footnotetext{
5 BEER Historical electricity data: 1920-2007 (file 40583).

${ }^{6}$ By 1938, 60\% of the gas industry's output was for domestic purposes (Ashby and Anderson, 1981). Household grid connections rapidly increased from $32 \%$ in 1931 , $65 \%$ in 1938 , to $96 \%$ in 1961 (Corley, 1966).
}

Table 3

Index of relative labour costs per tonne of saleable coal, 1935 (British costs $=100$ ) (Buxton, 1979: 57).

\begin{tabular}{lc}
\hline Country & Index \\
\hline Poland & 48 \\
USA (bituminous) & 61 \\
Germany (West Upper Silesia) & 68 \\
Belgium & 81 \\
Germany (Ruhr) & 96 \\
Great Britain & 100 \\
USA (Antracite) & 130 \\
France & 145 \\
\hline
\end{tabular}

and coal gas exerted limited market pressure since both used coal as feedstock and thus formed growth markets (Fig. 1).

Labour relations: Since their defeat in the 1926 strike, unions had lost some bargaining power. Wages decreased substantially (Fig. 10). Nevertheless, the proportion of British labour costs to total costs remained high by international standards (Table 3 ).

Decreasing wages and increasing unemployment spurred bitter labour relations. To protect jobs, unions did not wholeheartedly cooperate in the introduction of mining innovations (Court, 1945).

Policy: Policymakers stepped in to provide protection against economic pressures. ${ }^{7}$ The Coal Mines Act (1930) allowed the formation of cartels, which restricted output and guaranteed minimum prices. It also intended to stimulate industry consolidation (Allen, 1970). The Act was motivated by: (a) accumulated frustrations about the industry's inability to put its own house in order (Supple, 1988), (b) concerns about unemployment and social disruption of mining communities, (c) electoral interests and political pressure from labour unions. Policymakers paid limited attention to smoke problems, because economic issues took precedence.

Social movements: The smoke abatement movement continued its public information activities (Stradling and Thorsheim, 1999). A leading activist still saw the lack of public awareness as a major barrier: "Until every citizen recognises the fact that he or she is the cause of the dirty fogs nothing really adequate and valuable in the progress towards our objective, "clean air", can come to pass" (Des Voeux, 1934, The Times, 2 March 1934).

\footnotetext{
7 The British government introduced protective measures (tariffs, tolerance for collusion) in many industries in the interwar period (Bowden and Higgins, 2004).
} 
Public opinion: New visions of domestic life, which were advocated by the gas and electricity industries, began to erode coal's cultural legitimacy in the 1930s. The electricity industry disseminated visions about the all-electric house that was modern, efficient, clean, and hygienic (Corley, 1966). The Gas Council released movies such as 'The Smoke Menace' (Taylor, 1937), emphasising the dangers of smoke and portraying gas users as progressive citizens contributing to reduction of a social nuisance. These new visions resonated with cultural discourses around 'modernity', 'convenience', 'cleanliness' and 'health'. Smoke thus became part of a larger cultural 'package' that framed coal as oldfashioned, dirty, smoky and unhealthy.

Summary: Fig. 11 schematically summarises the main external pressures and spillovers.

\subsubsection{Industry response strategies}

Economic positioning strategy: The cartel structure reduced competitive incentives for innovation and efficiency improvements (Court, 1945), leading coal firms to focus on short-term survival and cost-reduction. The price of coal remained relatively stable (Fig. 8).

Innovation strategy: Since the late 1920s, coal firms accelerated the diffusion of coal cutters (Fig. 9), resulting in productivity improvements from 0.9 tonnes per manshift in 1925 to 1.2 tonnes per manshift in 1936 (Buxton, 1979). But these improvements remained slow by international standards. Mechanisation proceeded in a piecemeal fashion, focussing on individual components: "faceworking, roadway development, haulage, winding, ventilation, and lighting all needed to improve together, if the technological improvement of one of them was not to have its benefits reduced by the stagnant techniques of others" (Ashworth, 1986: 63). Technical inertia in the coal industry had several causes ${ }^{8}$ : (a) cartel legislation removed selection pressure and led firms to postpone expensive and systemic technical re-equipment (Court, 1945), (b) the mindset and identity of managers was characterised by rent-seeking instead of entrepreneurship and a preference for craft-based styles over science and engineering (Buxton, 1970; Dintenfass, 1992), (c) labour unions resisted the introduction of machines, (d) firms had limited resources for investment because of low profitability in preceding years (Buxton, 1979), (e) firms delayed investment in comprehensive modernisation because of uncertainties about market recoveries (Bowden and Higgins, 2004).

In terms of product innovation, the industry developed new appliances that produced less smoke. Diversification into smokeless fuels remained limited. To inform consumers about new appliances and more efficient coal use, the Coal Utilisation Council (CUC) was created in 1932.

Political strategies: The coal industry accepted cartel regulations but lobbied against industry consolidation. Sustained resistance culminated in the dissolution of the Coal Mines Reorganisation Commission in 1936 (Ashworth, 1986).

Framing strategies: The industry made some attempts to restore coal's reputation. The CUC chairman wrote: "But why must the word "old-fashioned" and "coal-kitchener" be necessarily coupled together? There are many new-fashioned and highly efficient cookers and ranges already on the market which consume coal with little if any smoke" (The Times, 3 March, 1934).

\subsubsection{Regime commitment}

Industry actors remained committed to industry regime, but made some small adjustments. Despite substantial economic problems, industry actors did not adopt comprehensive innovation strategies to close productivity gaps with foreign mines.

\footnotetext{
8 Many British industries were characterised by ‘defensive and cautious reactions' and 'failures to adapt' in the interwar period (Bowden and Higgins, 2004).
}

Instead, they implemented piecemeal mechanisation (and diversified somewhat into new products such as smokeless fuels). Industry actors remained committed to institutional logics of the existing regime: (a) the industry's mission and identity remained those of the 'Age of Coal' (a supply-side oriented extraction industry); (b) the core belief was that Britain was built on coal in the past and would remain so in the future; (c) technical operations remained relatively labour-intensive and craft-based (mechanisation was piecemeal). Major changes did occur in the governance dimension of the industry regime: the 1930 Coal Mines Act provided protection against economic pressures (and arguably allowed other regime elements to remain relatively unchanged).

\subsection{Nationalisation, post-war reconstruction and the Clean Air Act (1946-1956)}

\subsubsection{Pressures in economic and socio-political environment}

Markets: World War II depressed domestic markets and collapsed export markets (Fig. 1). Demand for coal picked up in the post-war reconstruction period, especially in the electricity, gas, iron/steel and heavy industries. Demand from railways decreased, because of increasing competition from diesel- and electric-powered locomotives. ${ }^{9}$ To prioritise industries, policymakers rationed growing household demand. The coal industry faced difficulties meeting this growing demand, because it "came out of the Second World War a vulnerable, smaller, and enfeebled industry" (Supple, 1987: 10).

Technical alternatives: Coal shortages stimulated the rise of (fuel) oil in iron, steel and heavy industries. Nuclear power appeared as a promising option in electricity generation. Households increased their use of gas and electricity.

Policy: The coal industry was nationalised (1946) for several reasons ${ }^{10}$ : (a) to increase control over industries with perceived economic importance, (b) to improve efficiency and productivity (there was accumulated frustration over the industry's inability to consolidate, rationalise and mechanise (Allen, 1970)), (c) to resolve deep-rooted labour problems (Hannah, 2004). The government initially adopted a hands-off approach, leaving day-to-day management to the newly created National Coal Board (Ashworth, 1986). The NCB had to rationalise the fragmented sector, modernise the mines, invest in $R \& D$ and create an efficient national enterprise, while maintaining an acceptable price of coal (Fig. 8). Financial support underpinned the Plan for Coal (1950), a long-term scheme for modernisation, mechanisation and reorganisation. The immediate short-term goal, however, was to increase coal output (Ashworth, 1986). The NCB was granted exclusive license to import, providing protection from foreign competition. Other relevant energy policies included coal rationing for households (until 1958), encouragement of oil use in power stations and industry, and nuclear power ambitions.

The 1952 Great London Smog, which caused over 4000 excess deaths, was a major shock that created credibility pressures on policymakers (Thorsheim, 2006). The government reluctantly installed the Beaver Committee (1953). The Beaver report (1954, p. 6) defined smoke as "a social and economic evil" and called for an $80 \%$ reduction in coal smoke over 15 years and legislation to achieve this (Ashby and Anderson, 1981). In 1955, an internal Cabinet memorandum assessed that "public opinion is ready for a strong

\footnotetext{
${ }^{9}$ The brief increase of railway coal consumption in the late 1950 s was due to a new construction programme, which resulted in 1518 steam locomotives between 1948 and 1956 (Chick, 1998). This programme was based on beliefs by railway executives that steam would remain the principle source of power.

10 Other strategic industries (e.g. steel, railways, electricity, gas) were also nationalised.
} 
government lead and would support measures on the scale proposed. Indeed, we do not think that anything less than positive action on a national basis would satisfy public opinion, or prove effective in abating pollution" (cited in Thorsheim, 2006: 181). This assessment led to the 1956 Clean Air Act (CAA), which began restricting household coal use and enabled cities to create smokeless areas. It also provided grants for the conversion of domestic grates to burn smokeless fuels (Ashby and Anderson, 1981).

Public opinion: The 1952 disaster shocked public opinion and placed smoke high on public agendas (Sanderson, 1961). It reinforced the public perception that coal was old-fashioned and outdated, and damaged coal's cultural legitimacy. Letters and newspaper reports also created pressure on policymakers.

Labour relations: Labour unions emerged from the war with a stronger bargaining position, and successfully argued for a substantial role in the nationalised industry (Brown, 2004). Strikes led to higher wages in the 1950s.

Summary: Fig. 12 schematically summarises the main external pressures and spillovers.

\subsubsection{Industry response strategies}

Economic positioning strategies: Expanding markets and government support created new industry optimism: "It is clear that industry and domestic consumers will continue to burn a very large tonnage of solid fuels" (NCB, 1953: 34). Alternative fuels (gas, electricity, oil) were not perceived as threats, but as allies in temporarily addressing fuel shortages: "maximum use must be made of other fuels to fill the gap" (NCB, 1954: 27).

Innovation strategies: The Plan for Coal (1950) assumed that demand would increase to 240 mtons/year by $1961-1965$, and asked for $£ 635$ million of government investments to boost output through the introduction of power-loading, locomotive haulage, winding techniques, horizontal mining and training schemes for mining engineers (Allen 1970). Implementation of modernisation plans was slow, because of: (a) under-developed managerial and administrative skills (Hannah, 2004), (b) shortage of engineers, and (c) tensions between short-term output maximisation and long-term reconstruction (Ashworth, 1986). Productivity therefore improved only slowly, rising from 1.23 tonnes per manshift in 1950 to 1.30 in 1958 (Ashworth, 1986). An interim evaluation, Investing in Coal (1956), increased estimated investments to $£ 1000$ million arguing that "the outlay proposed is large, but essential for the creation of the efficient and expanding coal industry on which the future of the British economy depends".

The industry also diversified into smokeless fuels (such as coke and briquettes), which resulted from process treatments of coal (e.g. carbonisation). This required the build-up of new chemical and thermal engineering capabilities and heavy capital expenditures. Plans for new coke ovens were implemented slowly, however, because they conflicted with output maximisation requirements for mining operations (Ashworth, 1986). The coal industry also engaged in appliance innovation, developing adjusted stoves and furnaces that better burnt smokeless fuels.

The NCB also invested in research, creating the Coal Research Establishment (CRE) in 1948 and the Mining Research Establishment (MRE) in 1952. The CRE focused on coal quality, briquetting, the mine environment and carbonisation, while the MRE applied engineering principles to underground mining (Ashworth, 1986).

Framing strategies: While the coal industry acknowledged the need to address smoke problems, it defended the continuation of coal (Sanderson, 1961; Scarrow, 1972), arguing that that the problem was the incorrect use of coal in old appliances. The coal industry and CUC therefore advocated new appliances, smokeless fuels, and consumer education as solutions (Sanderson, 1961).

Political strategies: The coal industry and FBI successfully lobbied to weaken the Clean Air Act. "It was indisputable that a lot of the concessions had been made in order to make the Bill palatable" (Ashby and Anderson, 1981: 114).

\subsubsection{Regime commitment}

Industry governance changed again with the 1946 nationalisation. Together with expanding markets this created new industry confidence. The Plan for Coal (1950) signalled an ambition to change technical capabilities (mine mechanisation and modernisation), but lacked urgency in its implementation. Commitment to diversification (smokeless fuels) was also limited, leaving the industry unprepared for the CAA. While some regime elements were changed (governance and technical capabilities), others were reinforced, e.g. the belief that coal would remain the primary fuel and those alternatives would (temporarily) fill supply gaps. The industry underestimated the threat from alternatives and ignored structural problems (slow mechanisation, low productivity, weak international competitiveness).

\subsection{Destabilisation: the way to the four-fuel economy (1956-1967)}

\subsubsection{Pressures in economic and socio-political environment}

Markets and technical alternatives: After 1957, overall coal demand declined (Fig. 1). Alternatives increasingly displaced coal in various market segments. Oil use tripled between 1960 and 1973, to nearly 50 million tonnes of coal equivalent (Fouquet, 2008), substituting for coal in gas works, iron/steel and heavy industries and on the railways (Allen, 1970). Coal sales to power stations increased but represented a decreased percentage of the power fuel mix. Fuel oil was also used for heating in commercial and industrial premises and (some) households. Nuclear energy, on-stream by 1959 , competed with coal in power generation. Between 1960 and 1965 , about $20 \%$ of commissioned future power station capacity was nuclear (Ashworth, 1986). Natural gas, discovered in the North Sea in the mid-1960s, began replacing coal gas in the late 1960s. Household coal use began declining after the 1956 Clean Air Act, which enabled cities to create smokeless areas. Heavy industry and power stations declined and relocated to more rural areas. By 1970 , 5 million premises were covered by smoke control orders, rapidly reducing smoke emissions (Turnheim and Geels, 2012). The primary growth market for coal was electricity generation (Fig. 1). Coke and solid smokeless fuels also formed growth markets until the late 1960s when natural gas began to replace coal gas. ${ }^{11}$

Policy: In the late 1950s, macro-economic concerns over inflation, the balance of payments and Britain's international competitiveness formed the background for policies that increased pressure on the coal industry. With the creation of the Select Committee on the Coal industry (1957), public scrutiny of the NCB increased (Ashworth, 1986). The government wanted to downscale financial support for several reasons: (a) a desire to decrease public spending (Brown, 2004), (b) frustrations over escalating costs of industry modernisation plans (Ashworth, 1986), (c) positive expectations about nuclear energy. Coal policy subsequently changed from supporting expansion towards 'controlled rundown'. The Revised Plan for Coal (1959) focused investments on fewer mines and closed small and inefficient pits. A 1961 White Paper (Cmnd 1337) stipulated that nationalised industries should become self-supporting. This policy threatened the coal industry, which had experienced losses in the four preceding years. The Conservative government made some concessions, providing ongoing protection through cheap loans, contracts for coal use in public buildings, contracts for power stations, and an excise duty on fuel oil

\footnotetext{
11 Coke was a by-product of coal gas production.
} 


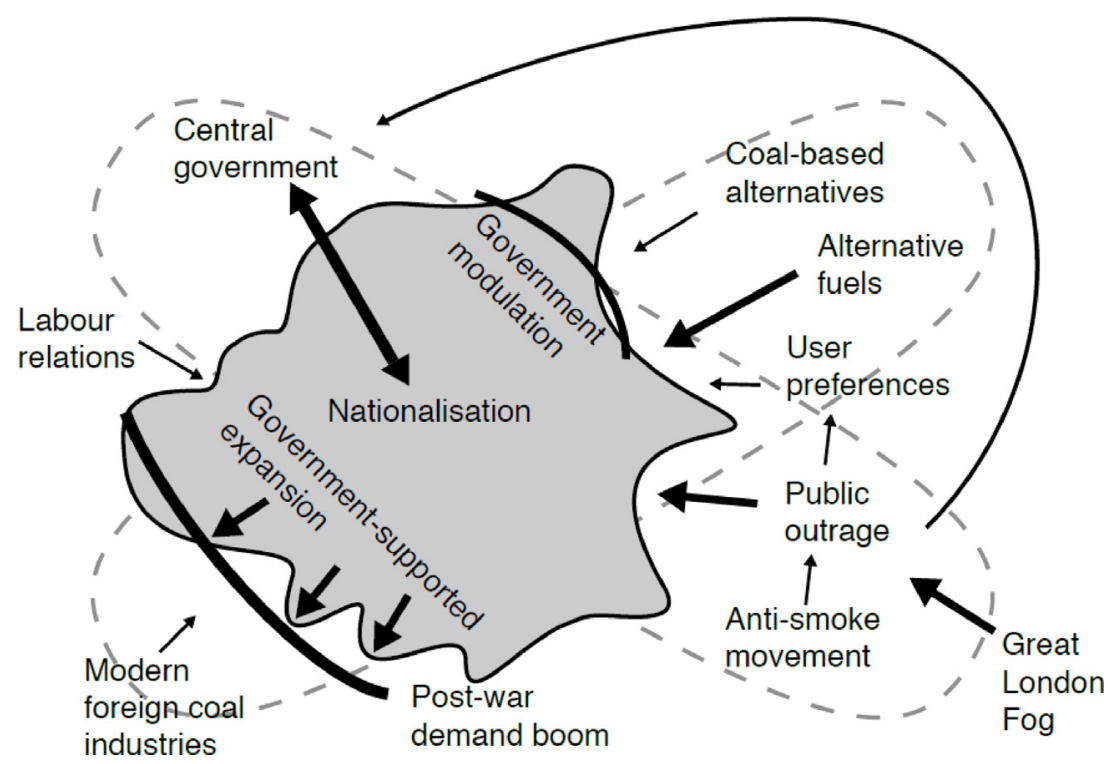

Fig. 12. Multi-dimensional pressures and spillovers (1946-56).

(introduced in 1961) (Allen, 1970; Ashworth, 1986). These protective measures were later downscaled by the 1965 White Paper on Fuel Policy, which unleashed market forces. The White Paper institutionalised the shift towards a four-fuel economy, with decreasing shares for coal, and increasing shares for nuclear power, natural gas, and oil. This policy change was the result of political enthusiasm about nuclear power and natural gas, accumulated frustration about slow mine modernisation and industry subsidies, and eroded cultural legitimacy ('outdated' and 'old-fashioned'). The reduction in coal production estimates (to 170-180 mtons in 1970) required "the most dramatic and ruthless contraction of the industry in postwar history" (Turner, 1989: 156). Although a declining coal industry was now seen as inevitable, policymakers were concerned about social and economic costs. To soften the impact, the government granted the coal industry long-term supply contracts for electricity generation (NCB, 1964), and wrote-off almost half of its debts ( $£ 415$ million).

Labour relations: Labour relations soured in the late 1950s when the government became concerned about inflation, which it linked to wage rises (Brown, 2004). Throughout the 1960s, governments tried to persuade or coerce unions to moderate wage claims, creating a recurring source of tension.

Public opinion: The wider public perceived coal as outdated and dirty, despite the reduction of smoke problems. The coal industry also lost its 'special status' as newer industries captured the public imagination.

Summary: Fig. 13 schematically summarises the main external pressures and spillovers in the 1957-1965 period. After 1965 the coal industry assumed a new form, which remained stable for a decade: a much smaller industry dedicated to a single market

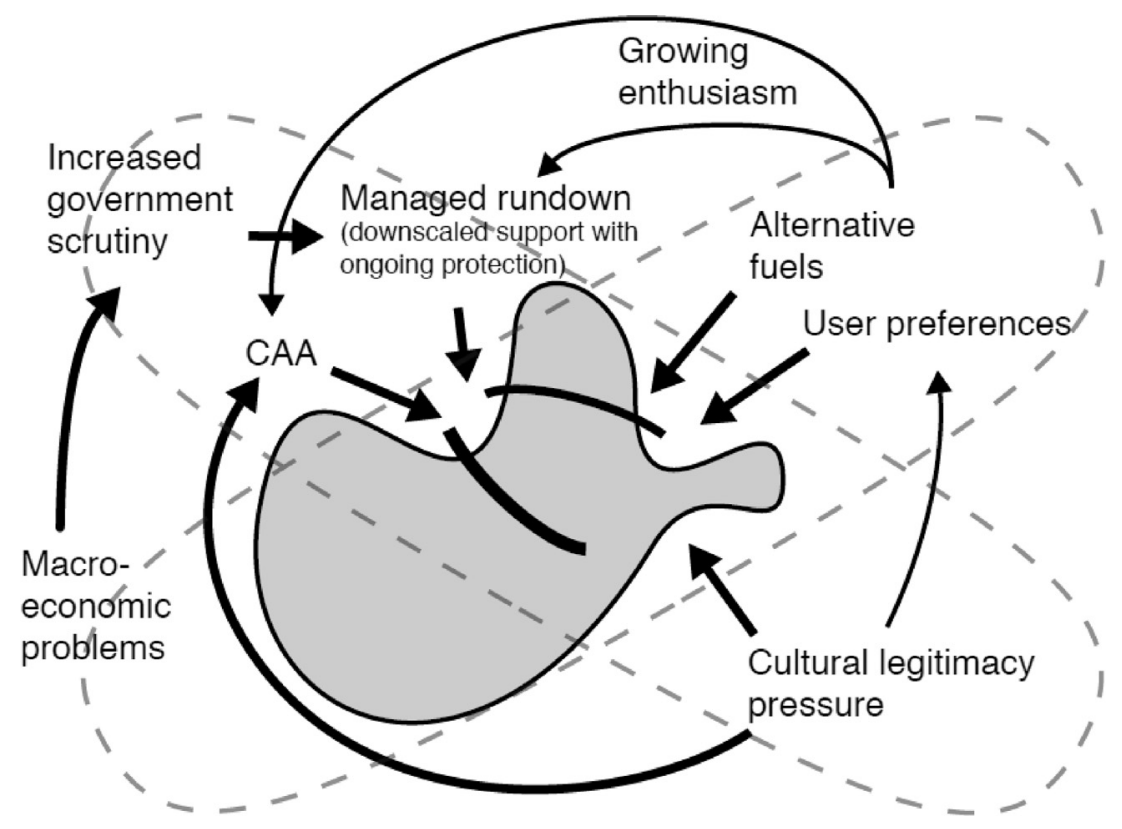

Fig. 13. Multi-dimensional pressures and spillovers (1957-1965). 


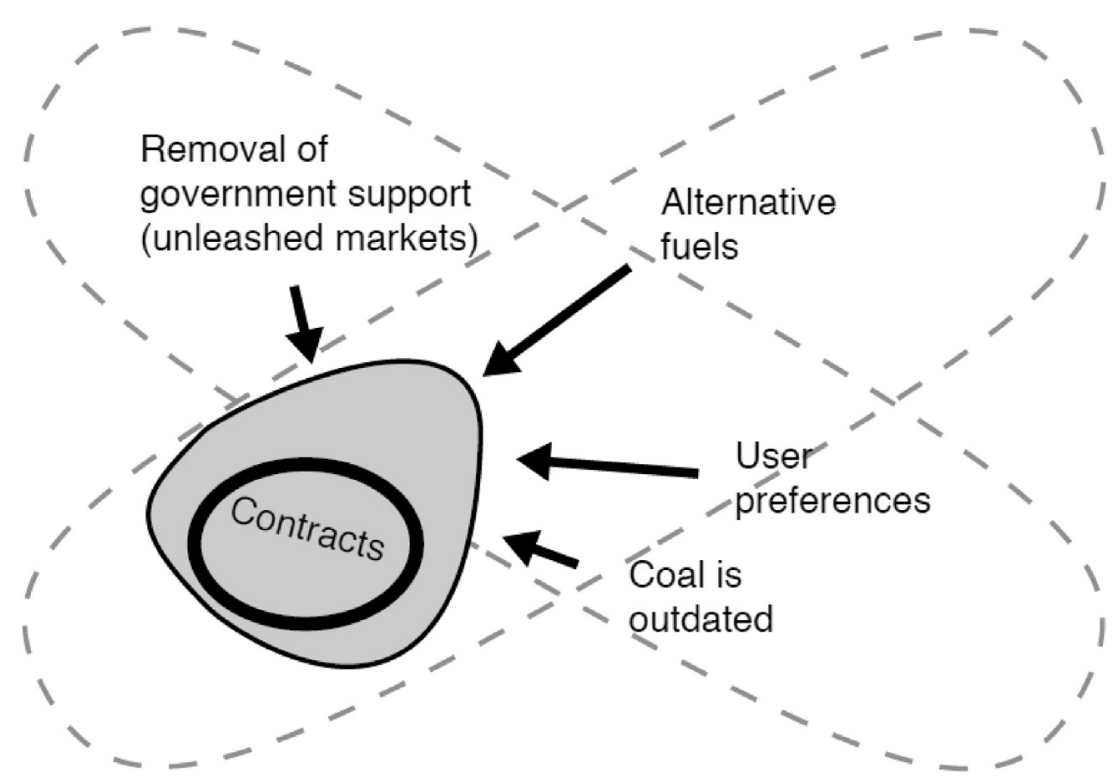

Fig. 14. New state after destabilisation (post-1965).

(power generation), underpinned by government-supported contracts (Fig. 14).

\subsubsection{Industry response strategies}

Economic positioning strategies: In 1957, coal industry actors still believed in a bright future, expecting coal production to increase steadily to 250 million tonnes by 1970 (Fig. 15). The easing of fuel shortages also contributed to industry confidence:

"For the first time perhaps since the 1914 war, British Coal and every man in it can see clearly ahead to a future based on a secure and vital place in the national economy" (NCB, 1957: 23).

The 1958 sales decline (of 13 million tonnes) was not interpreted as a structural development: "the period of recession in some British industries was a temporary setback in a long-term trend of industrial expansion" (NCB, 1958:3).
But when declining markets accelerated financial losses in 1959 and 1960 (Turnheim and Geels, 2012), the industry became more concerned, adopting defensive strategic orientations:

"The Board's objective of a market for coal at around 200 million tons a year can be achieved by holding those markets where coal can effectively compete and by winning a share of the new business arising from future economic growth. Competition in the energy market is expected to remain fierce over the next few years" (NCB, 1962: 14-15).

Concerns evolved into a loss of confidence, because of the 1965 White Paper, which projected rapid declines of coal.

“The Government's White Paper "Fuel Policy" contained estimates that by 1970 the market for coal was unlikely to exceed 170-180 million tons a year. These estimates (...) led to a loss of confidence within the industry." (NCB, 1965: xi)

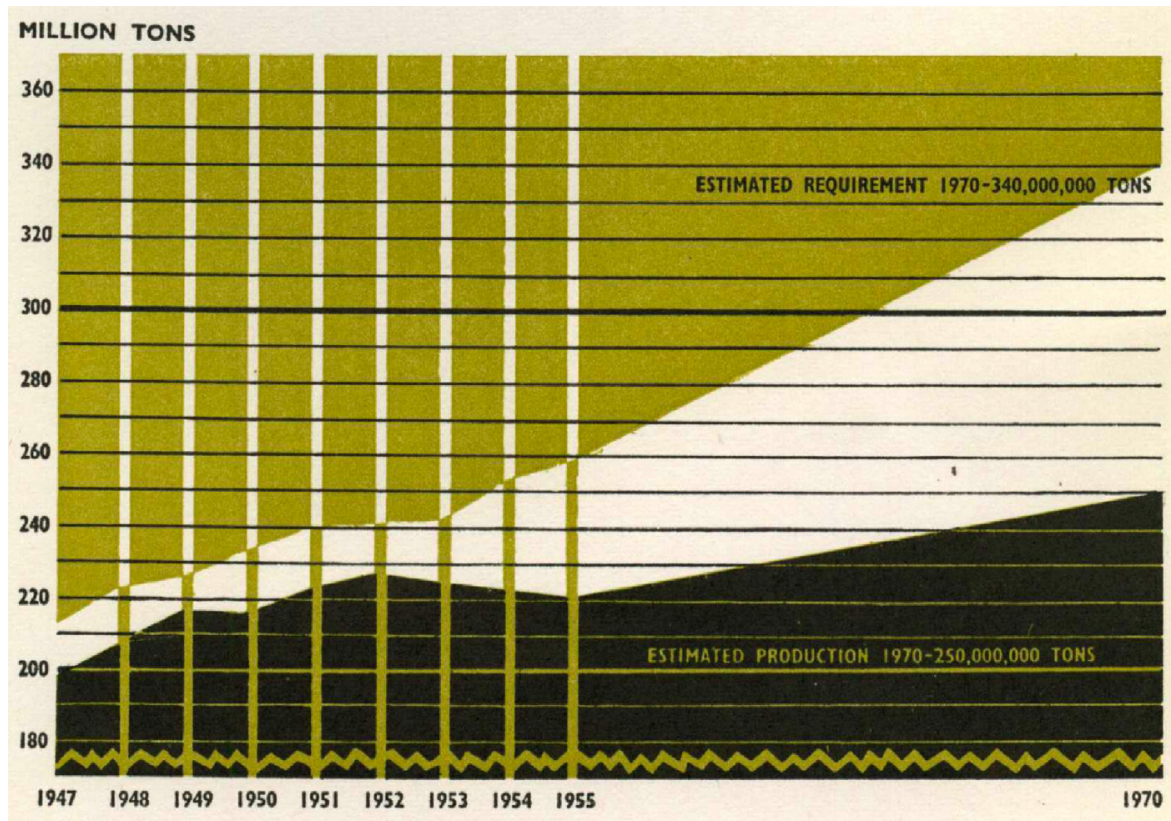

Fig. 15. Actual (until 1955) and estimated coal production (bottom area) and total energy consumption in coal equivalent (middle area) (NCB, 1957: 8). 


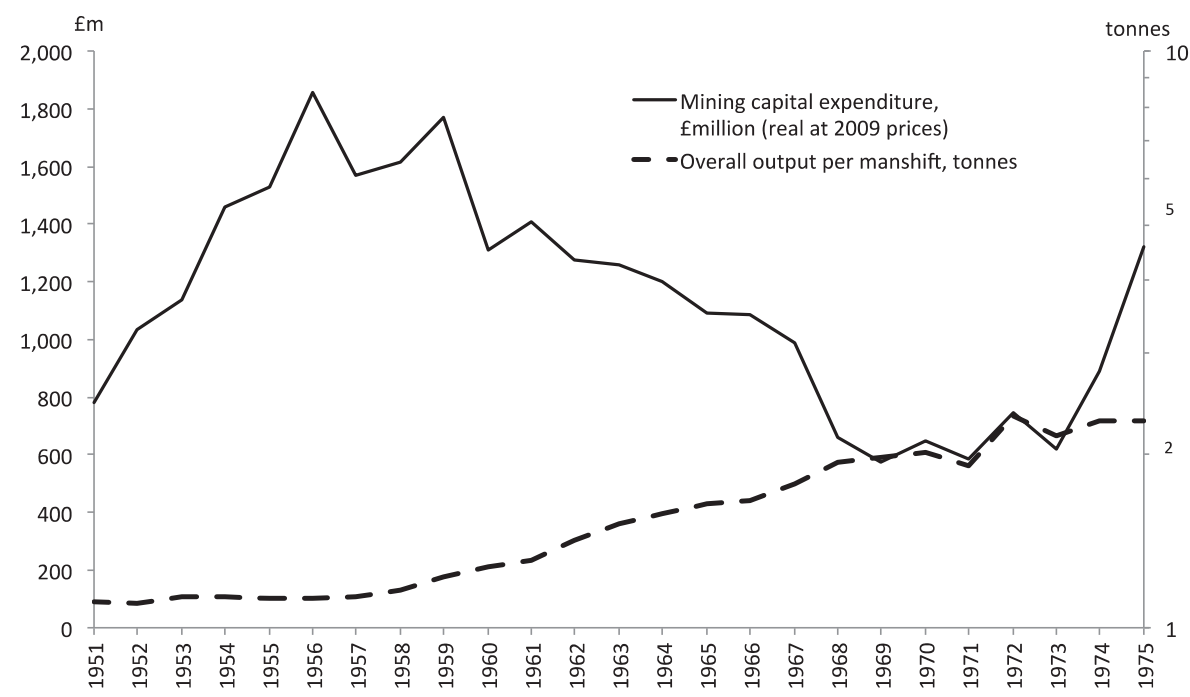

Fig. 16. Productivity and mining capital expenditure in the British coal industry (Data: NCB Annual Reports; Townsend, 1976).

Accelerated mine closures caused "cynicism and demoralisation in the mining industry" (Robens, 1972: 170). The loss of government (financial) support reduced the industry's ability to mitigate coal price rise under adverse market conditions. After 1965, coal prices rose rapidly (Fig. 8), which decreased the industry's competitiveness.

Innovation strategies: While the strategic orientation changed from confidence to loss of faith within a few years, the industry transformed itself through various innovation strategies. The Revised Plan for Coal (1959) accelerated mine modernisation by improving mine layouts and tunnelling methods. The enhanced use of power-loaders, coal-cutters and conveyor belts transformed mining into an integrated continuous flow industry (Ashworth, 1986). Productivity (output per manshift) increased substantially, from 1.25 tonnes in 1957, to 1.56 tonnes in 1962 and 2.1 tonnes in 1968 (Allen, 1970; Fig. 16). This improvement was also due to closure of inefficient mines and focusing investment on fewer, more productive mines.

To support the modernisation programme, the industry created an integrated innovation system in which the newly-created Central Engineering Establishment (1956), which addressed practical developments and technology testing, interacted with CRE and MRE researchers, users, and equipment manufacturers (Ashworth, 1986).

The industry also developed second-generation smokeless fuels, which could be used in existing appliances and grates (Ashworth, 1986). Despite R\&D successes, the coal industry failed to rapidly increase its smokeless fuel capacity. The NCB chairman blamed the government for not providing sufficient investments: "It was clear from our own experience as producers of smokeless fuels that a fantastic amount of capital would be needed to build smokeless fuel plants and that this would not be forthcoming" (Robens, 1972: 61).

The industry also collaborated with appliance manufacturers to improve domestic stoves and develop new central heating systems, enabling it to move into new markets (central heating), where coal secured a lead position until the rise of natural gas in the late 1960s (Ashworth, 1986). The coal industry also explored service-oriented business models such as "selling heat not fuel" (NCB, 1967: 23).

More generally, marketing strategies began to pay more attention to customers, whom the industry had long taken for granted. Accordingly, the NCB expanded sales services and advertising (NCB 1959).

Political strategies: The coal industry employed political strategies to hinder implementation of the Clean Air Act (Scarrow, 1972).
The industry also lobbied local councils to secure coal markets for individual electricity plants. "We widened our attack on other authorities and got the cooperation of people in the industry who served on local authorities to press our case, using briefs that we supplied to them" (Robens, 1972: 68). The NCB chairman also pushed to acquire planning permissions:

"the [Central Electricity Generation Board] were finding it difficult in the 1960s and onwards to get planning permission for new stations, and I weighed in to help them where a coal-fired station was involved. It was a mixture of propaganda and politics" (Robens, 1972: 66).

Framing strategies: In response to negative framings, the industry tried to restore its reputation by engaging in public relations activities, e.g. the 'cosy coal fire' advertising campaign. It also framed coal and new appliances as 'modern': "One of the Board's tasks is to make clear that coal - as distinct from some of the appliances in which it is still being burnt - is not "old-fashioned" (NCB, 1960: 7). In 1960, the NCB launched the "progressive industry is going forward on coal' campaign, which linked coal to modern industries (Fig. 17).

In response to a critical political discourse (about featherbedding and protection of the coal industry) the industry developed a counter-discourse (Robens, 1972), arguing that: (1) coal was the only indigenous fuel with proven long-term reserves; (2) the industry was a major employer, and downscaling would have major social costs; (3) investments were beginning to boost productivity; and (4) phasing out coal was a waste of past investments. ${ }^{12}$ This had little effect on political outcomes. Following the 1965 White Paper, the industry could do little more than complain about "excessive national commitments to the development of natural gas and nuclear power" (NCB, 1967:8) and make pleas for (some) ongoing support (via obligations and contracts).

\subsubsection{Regime commitment}

The commitment to the regime's institutional logics collapsed in the late 1950s and early 1960s, when increasing and aligning pressures caused financial and legitimacy problems (which translated into downscaled support). Because the industry was

12 “Since $1947, £ 1300$ million have been invested in the coal industry (...). There is no national advantage to be gained from not using to the full the resources of an industry in which so much has been invested." (NCB, 1964: 5). 


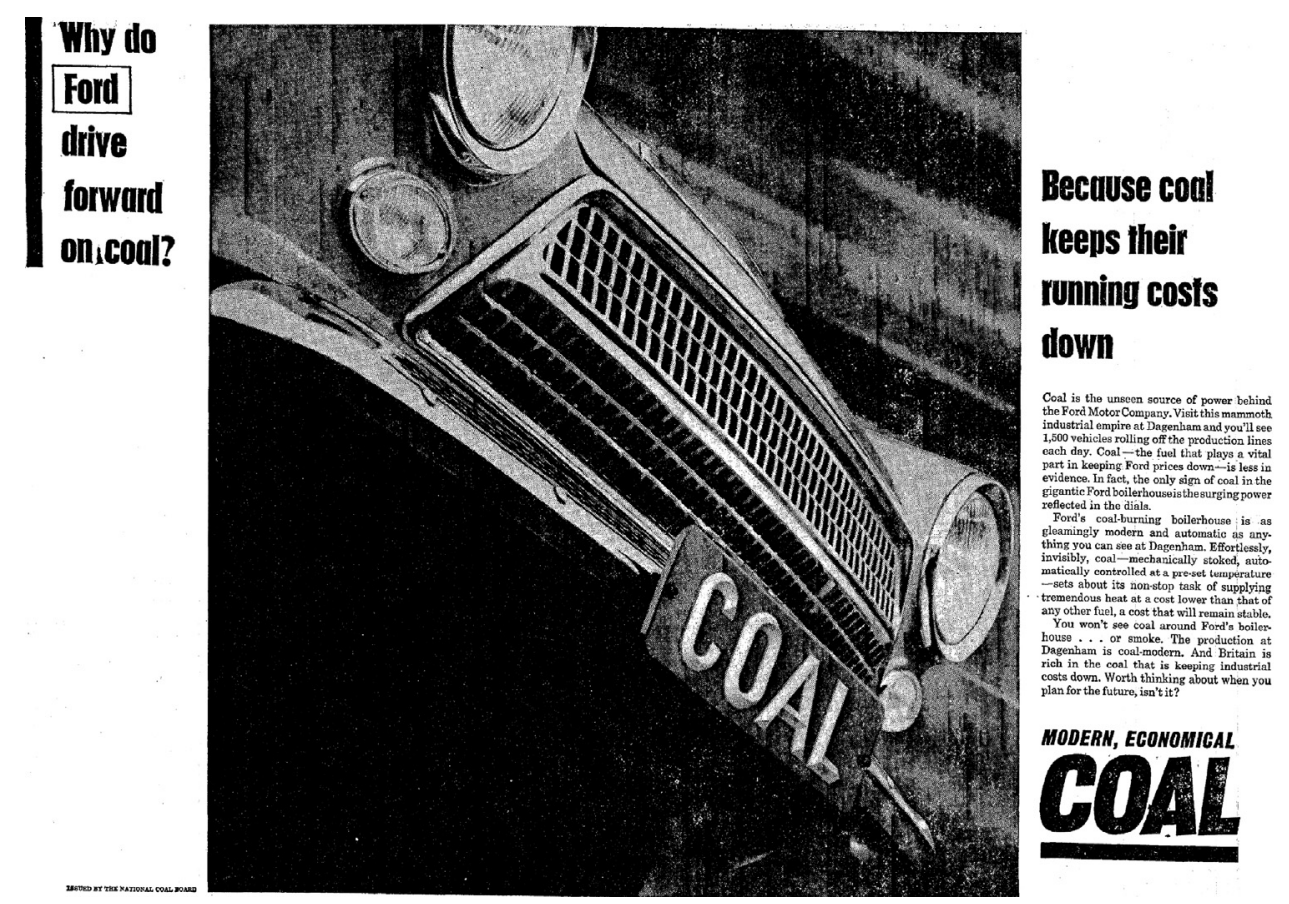

Fig. 17. NCB advertisement in the 'Progressive industries' campaign (The Times, 24-03-1964).

relatively unprepared, these problems caused a sense of crisis, leading to various change programmes (Revised Plan for Coal, advertising campaigns, frantic struggle for markets). The 1965 White Paper destroyed the industry's hope of restoring coal markets, leading the NCB to talk about loss of confidence and demoralisation. Subsequently, industry actors recreated institutional logics of the industry regime: (a) industry beliefs changed, recognising the threat from alternatives and accepting that coal was only one fuel amongst others, that it could not take customers for granted, and that the electricity industry increasingly formed its lifeline; (b) mission and identity changed to encompass supply and demand-side issues (causing increased attention for fuel consultancy, appliances, central heating, district heating, energy services); (c) in terms of technology, the industry modernised the remaining mines, accelerated smokeless fuels processing, and created an integrated innovation system.

\section{Analysis}

\subsection{Pattern matching}

Our model suggested that destabilisation entails three interacting processes: (1) accumulation of external pressures, (2) decreasing performance (financial and legitimacy) triggers industry responses towards external environments, (3) gradual weakening of commitment to established regime elements, progressing through several stages: (a) retrenchment, (b) local search and incremental innovation, (c) more distant search and strategic 'reorientation' towards technical alternatives, (d) questioning of core beliefs, mission and business models, leading to strategic 'recreation'.

The case study had a relatively good fit with this model:

- In the first period (1913-1930), economic problems (related to shrinking markets and new entrants) and legitimacy pressures (about coal smoke and miner conditions) were downplayed and led to minor regime-reinforcing adjustments (wage cuts, piecemeal mechanisation).

- Only when economic pressures became more serious (in the 1930s), with visible consequences on economic performance (bankruptcies) and political legitimacy (early policy concerns about viability), did the industry fully recognise its structural problems. Nevertheless, actors implemented incremental response strategies (piecemeal mechanisation) and market protection (cartelisation and import restrictions) that ensured short-term survival within the bounds of the existing regime.

- The post-war reconstruction period halted (and concealed) further progression of economic and legitimacy problems. Expanding markets and government support (following nationalisation) created opportunities for technical modernisation and product diversification (smokeless fuel). This enabled 'unlocking' of the old craft-based technical regime. Commitment to other core regime rules (beliefs, mission, identity) was reinforced. But at the same time, economic performance stagnated (slow productivity improvements, dependence on government funding). Furthermore, the Great London Smog (1952) led to regulations favouring alternatives.

- From the mid-1950s, economic and socio-political pressures resurfaced (shrinking markets, penetration of alternatives), eroding the industry's economic performance (profits) and legitimacy (political frustration, negative cultural discourse). Policy enthusiasm shifted to alternatives (nuclear, oil), and the industry adapted only sparsely to the smoke challenge. Despite increasing doubts, industry hopes lived on. But between 1959 and 1965 these hopes were dashed, because of policy change and declining markets. The industry re-created itself by concentrating on steam coal for power generation. The destabilisation of the old regime was thus accompanied by recreation of a new regime (including new technologies, beliefs, mission, business model).

The main deviation from the model is that 'distant search' and technical reorientation in the post-war decade was driven more by positive opportunities than by increasing pressures. 
Table 4

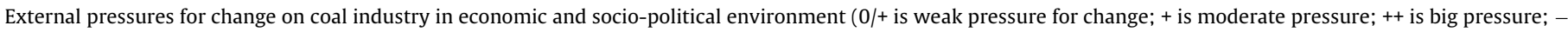
is stabilising external pressure; - is major stabilising pressure).

\begin{tabular}{|c|c|c|c|c|c|c|c|}
\hline & $\begin{array}{l}\text { Shrinking } \\
\text { markets }\end{array}$ & $\begin{array}{l}\text { Changing } \\
\text { markets and } \\
\text { preferences }\end{array}$ & $\begin{array}{l}\text { Technological } \\
\text { competition }\end{array}$ & New entrants & $\begin{array}{l}\text { Normative } \\
\text { contestation }\end{array}$ & $\begin{array}{l}\text { Public opinion } \\
\text { and discourse }\end{array}$ & Political pressure \\
\hline 1913-1930 & $\begin{array}{l}++ \\
\text { Especially } \\
\text { export decline }\end{array}$ & & $\begin{array}{l}\text { Coal gas and } \\
\text { electricity in } \\
\text { upper class } \\
\text { households }\end{array}$ & $\begin{array}{l}++ \\
\text { Foreign } \\
\text { competition in } \\
\text { export markets }\end{array}$ & $\begin{array}{l}+ \\
\text { Growing } \\
\text { anti-smoke } \\
\text { movement, } \\
\text { alliance with } \\
\text { alternatives }\end{array}$ & $\begin{array}{l}\text { - Public } \\
\text { support for } \\
\text { coal (jobs and } \\
\text { prosperity) }\end{array}$ & $\begin{array}{l}0 /+ \\
\text { Govt investigates } \\
\text { industry problems; } \\
\text { weak } 1926 \text { smoke } \\
\text { regulations }\end{array}$ \\
\hline 1930-1946 & $\begin{array}{l}+ \\
\text { Export decline; } \\
\text { home } \\
\text { stagnation }\end{array}$ & $\begin{array}{l}+ \\
\text { New user } \\
\text { preferences } \\
\text { coupled to new } \\
\text { cultural } \\
\text { repertoires }\end{array}$ & $\begin{array}{l}0 /+ \\
\text { Early } \\
\text { competition } \\
\text { from gas and } \\
\text { electricity in } \\
\text { specific } \\
\text { markets }\end{array}$ & $\begin{array}{l}+ \\
\text { Foreign } \\
\text { competition in } \\
\text { export markets }\end{array}$ & $\begin{array}{l}+ \\
\text { Public } \\
\text { education } \\
\text { activities; } \\
\text { alliance with } \\
\text { alternatives }\end{array}$ & $\begin{array}{l}+ \\
\text { Critical coal } \\
\text { discourse but } \\
\text { limited public } \\
\text { concern about } \\
\text { smoke }\end{array}$ & $\begin{array}{l}\text { - Economic } \\
\text { government } \\
\text { protection (price } \\
\text { control, cartel) }\end{array}$ \\
\hline 1946-1956 & $\begin{array}{l}\text { - } \\
\text { Post-war } \\
\text { market } \\
\text { expansion }\end{array}$ & $\begin{array}{l}\text { Growing } \\
\text { interest in } \\
\text { alternatives; } \\
\text { dissatisfaction } \\
\text { with coal }\end{array}$ & $\begin{array}{l}\text { Competition } \\
\text { from oil; plans } \\
\text { for nuclear; } \\
\text { diffusion of } \\
\text { coal gas and } \\
\text { electricity }\end{array}$ & $\begin{array}{l}\text { Coal imports } \\
\text { via NCB }\end{array}$ & $\begin{array}{l}\text { Great London } \\
\text { Fog boosts } \\
\text { credibilty }\end{array}$ & $\begin{array}{l}\text { Public outrage } \\
\text { over Great } \\
\text { London Fog }\end{array}$ & $\begin{array}{l}\text { Government support } \\
\text { (nationalisation and } \\
\text { modernisation } \\
\text { plans) }\end{array}$ \\
\hline 1956-1970 & $\begin{array}{l}++ \\
\text { Declining } \\
\text { markets; } \\
\text { power } \\
\text { generation is } \\
\text { the industry's } \\
\text { life line }\end{array}$ & $\begin{array}{l}++ \\
\text { 'Modern' } \\
\text { consumers and } \\
\text { industries } \\
\text { switch to } \\
\text { alternatives }\end{array}$ & $\begin{array}{l}++ \\
\text { Nuclear energy, } \\
\text { oil and } \\
\text { (natural) gas }\end{array}$ & & & $\begin{array}{l}\text { Coal is } \\
\text { outdated'; coal } \\
\text { industry seen } \\
\text { as less } \\
\text { attractive }\end{array}$ & $\begin{array}{l}\text { CAA; frustration } \\
\text { with coal and more } \\
\text { scrutiny; enthusiasm } \\
\text { for alternatives; } \\
1965 \text { White Paper }\end{array}$ \\
\hline
\end{tabular}

\subsection{Answering specific research questions}

Using the case study, we can now also provide (tentative) answers to the specific questions from Section 2.3.

\subsubsection{Regime inertia}

Strikingly, regime commitment remained relatively strong for 40 years (1913-1946), despite increasing pressures. Substantial changes in the governance system were implemented in the 1930s, but other regime elements remained relatively unchanged. This was followed by a decade of increasing doubts (1946-1959), further changes in governance system (nationalisation) and technology, and a rapid loss of faith (1959-1965), followed by changes in mindsets, mission and business model. These changes had characteristics of a crash programme when the damage had already been done in terms of cultural legitimacy, competitiveness and political support.

The case study thus confirms that industry responses to external pressures were slowed down by regime commitments, which hindered timely adjustments to changing circumstances. We further conclude that mindsets, mission and identity were regime elements with the highest degree of lock-in. These elements are fundamental and constitutive, shaping 'ways of being' for industry actors. Technological and regulatory regime elements relate to 'ways of doing things', which were comparatively easier to change.

\subsubsection{Linearity of pressures}

We summarised the main pressures and their increases/decreases in Table $4 .{ }^{13}$ This shows that only some pressures increased linearly (technical competition, public opinion) or were continuously present (normative contestation from smoke-abatement movements). Most other pressures alternated between positive and negative orientations. This suggests that one

\footnotetext{
13 The 'scoring' of pressure strength should only be read within columns, and cannot easily be compared across columns.
}

should analyse the $e b b$ and flow of external pressures rather than assuming linear increase.

\subsubsection{Relative importance of pressures}

The case study confirms the initial assessment of Turnheim and Geels (2012) that pressures in the economic environment were direct causes of full destabilisation: changing user preferences, technological competition, and shrinking markets ultimately undermined the industry's economic viability. Socio-political pressures acted as mediating factors that shaped the vulnerability of the industry to economic pressures. Political support (in the form of the 1930 Coal Mines Act and 1946 nationalisation) initially protected the industry from economic pressures. But downscaling of public support in the late 1950s unleashed economic forces, and thus contributed to destabilisation. This downscaling was related to decreasing cultural legitimacy (debates about coal as oldfashioned and outdated), changes in political discourse (criticism of 'featherbedding', ideals of self-supporting industry), accumulated policy frustration (about slow modernisation), and shifting political enthusiasm (to nuclear and gas).

\subsubsection{Multiplicity and alignments of pressures}

The case study and Table 4 clearly show that destabilisation entailed multiple pressures. For full destabilisation (1959-1965), crucial economic pressures came from technological competition and changing user preferences, which translated into shrinking coal markets. And in the socio-political environment crucial pressures came from changes in societal beliefs/discourses and changing government policies. Table 4 suggests that all pressures in the fourth period increased, aligned, and pointed in the same direction. We can thus characterise the overall pattern as a 'perfect storm' in which multiple aligning pressures overwhelmed and destabilised the coal industry regime.

The case also highlights the importance of multi-dimensional spillovers between. The various spillover figures $(7,11,12,13$, 14) show that technical, economic, political and cultural pressures influenced each other in longer interaction chains and cascading 
dynamics. These ubiquitous spillovers complicate assessments of the 'relative importance' of specific pressures (as we did under point c). They also underline the usefulness of the framework and the general importance of co-evolutionary analyses.

Additionally, we want to highlight the role of new technology, not just in exerting economic pressure, but also as a broader 'alignment catalyst'. The breakthrough of alternatives stimulated and coupled various pressures: gas and electricity actors collaborated with the anti-smoke movement and helped articulate a new cultural discourse; gas and electricity changed customer preferences and markets; political enthusiasm about nuclear and gas enhanced dissatisfaction with coal. New technologies thus enhanced the coherence and coupling of pressures and problems.

\section{Conclusions}

The destabilisation of industry regimes is an interesting but understudied topic. The paper has extended a multi-dimensional framework that integrates four existing views on destabilisation. Destabilisation is understood to entail interactions between three processes: accumulation of external (economic and socio-political) pressures, strategic responses to these pressures, (gradual) weakening of commitment to established regime elements. The multi-faceted framework enables rich empirical analyses that address contexts and agency, material dimensions (markets, resources, competition) and non-material dimensions (beliefs, attitudes, strategies). The case study confirmed the usefulness of the conceptual framework and the analysis provided specific conclusions about degrees of regime inertia, ebb and flow of external pressures, relative importance of pressures, and interactions between pressures.

Caveats are due with regard to generalisation. Because industry destabilisation is a multi-faceted process, it may follow different patterns, depending on interactions between external pressures (speed, size, directionality, spillovers), response strategies (beliefs, resource allocation decisions) and degrees of commitment. Rather than a single theory, we proposed a flexible conceptual framework that allows for multiple combinations between these core processes. We expect that these processes hold across a multiplicity of cases, while specific combinations can explain destabilisation patterns in individual cases, as we have shown for the British coal industry regime.

\section{Acknowledgements}

We want to thank the three reviewers, the special issue editors, Andy Stirling, Adrian Smith, Ed Steinmueller, Mike Parker and Peter Pearson for their useful feedback on previous versions of the paper. We also thank Roger Fouquet for sharing his dataset. This work has been supported by an ERC grant (No. 204246).

\section{References}

Allen, G.C., 1970. British Industries and their Organization, 5th edition. Longmans, London.

Abbott, A., 2001. Time Matters: On Theory and Method. University of Chicago Press, Chicago, IL.

Argyris, C., 1976. Singe-loop and double loop models in research on decision-making. Administrative Science Quarterly 21 (3), 363-375.

Ashby, E., Anderson, M., 1981. The Politics of Clean Air. Monographs on Science. Technology and Society. Clarendon Press, Oxford.

Ashworth, W., 1986. The history of the British coal industry. 1946-1982: The Nationalized Industry, vol. 5. Clarendon Press, Oxford.

Aminzade, R., 1992. Historical sociology and time. Sociological Methods and Research 20, 456-480.

Barker, V.L., Mone, M.A., 1994. Retrenchment: cause of turnaround or consequences of decline? Strategic Management Journal 15 (5), 395-405.

Barr, P.S., Stimpert, J.L., Huff, A.S., 1992. Cognitive change, strategic action, and organizational renewal. Strategic Management Journal 13, 15-36.
Barty-King, H., 1984. New Flame. How Gas Changed the Commercial and Industria Life of Britain between 1813 and 1984. Graphmitre Limited, Devon.

Baum, J.A.C., Powell, W.W., 1995. Cultivating an institutional ecology of organizations: comment on Hannan, Carroll, Dundon, and Torres. American Sociologica Review 60 (4), 529-538.

Bowden, S., Higgins, D.M., 2004. British industry in the interwar years. In: Floud, R. Johnson, P. (Eds.), The Cambridge Economic History of Modern Britain. Volume II: Economic Maturity, 1860-1939. Cambridge University Press, Cambridge, pp. 374-402.

Boyer, G., 2004. Living standards, 1860-1939. In: Floud, R., Johnson, P. (Eds.), The Cambridge Economic History of Modern Britain. Volume II. Economic Maturity, 1860-1939. Cambridge University Press, Cambridge, pp. 280-313.

Brown, W., 2004. Industrial relations and the economy. In: Floud, R., Johnson, P. (Eds.), The Cambridge Economic History of Modern Britain. Volume III. Structural Change and Growth, 1939-2000. Cambridge University Press, Cambridge, pp. 399-423.

Buxton, N.K., 1970. Entrepreneurial efficiency in the British coal industry between the wars. Economic History Review 23, 476-497.

Buxton, N.K., 1979. Coalmining. In: Buxton, N.K., Aldcroft, D.H. (Eds.), British Industry Between the Wars: Instability and Industrial Development 1919-1939. Scolar Press, London, pp. 48-77.

Chick, M., 1998. Industrial Policy in Britain 1945-1951. Cambridge University Press, Cambridge.

Church, R., 1986. The History of the British Coal Industry, Vol. 3, 1830-1913: Victorian Pre-Eminence. Clarendon Press, Oxford.

Collins, J., 2009. How the mighty fall and why some companies never give in. Random House, London.

Corley, T.A.B., 1966. Domestic Electrical Appliances. London.

Court, W.H.B., 1945. Problems of the British coal industry between the wars. The Economic History Review 15 (1-2), 1-24.

Den Hond, F., De Bakker, F.G.A., 2007. Ideologically motivated activism: how activist groups influence corporate social change activities. Academy of Management Review 32 (3), 901-924.

Dintenfass, M., 1992. Managing Industrial Decline: British Coal Industry Between the Wars. Ohio State University Press, Columbus.

Evans, R.J., 2000. In Defence of History. Granta Books, London.

Fouquet, R., 2008. Heat, Power and Light: Revolutions in Energy Services. Edward Elgar, Cheltenham.

Gaddis, J.L., 2002. The Landscape of History: How Historians Map the Past. Oxford University Press, New York [etc].

Geels, F.W., 2002. Technological transitions as evolutionary reconfiguration processes: a multi-level perspective and a case-study. Research Policy 31 (8-9), 1257-1274.

Geels, F.W., Schot, J.W., 2007. Typology of sociotechnical transition pathways. Research Policy 36 (3), 399-417.

Geels, F.W., 2013. Grand Societal Challenges and Industry-Environment Interactions: Developing a Multi-Dimensional Triple Embeddedness Framework, Research Policy, revised and resubmitted.

Giddens, A., 1984. The Constitution of Society: Outline of the Theory of Structuration. University of California Press, Berkeley [etc.].

Greasley, D., 1990. Fifty years of coal-mining productivity: the record of the British coal industry before 1939. Journal of Economic History 50, 877-902.

Griffin, L.J., 1993. Narrative, event-structure, and causal interpretation in historical sociology. American Journal of Sociology 98 (5), 1094-1133.

Grinyer, P.H., Spender, J.-C., 1979. Recipes, crises, and adaptation in mature businesses. International Studies of Management and Organization 9 (3), 113-133.

Hambrick, D.C., D’Aveni, R.A., 1988. Large corporate failures as downward spirals. Administrative Science Quarterly 33 (1), 1-123.

Hannan, M.T., Freeman, J.H., 1989. Organizational Ecology. Harvard University Press, Cambridge, MA.

Hannah, L., 2004. A failed experiment: the state ownership of industry. In: Floud R., Johnson, P. (Eds.), The Cambridge Economic History of Modern Britain. Volume III. Structural Change and Growth, 1939-2000. Cambridge University Press, Cambridge, pp. 84-111.

Harrigan, K.R., 1980. Strategy formulation in declining industries. Academy of Management Review 5 (4), 599-604

Hoffman, A.J., 2001. Linking organizational and field-level analyses: the diffusion of corporate environmental practice. Organization \& Environment 14(2), 133-156.

Lewin, K., 1947. Frontiers in group dynamics. In: Catwright, D. (Ed.), Field Theory in Social Science. Social Science Paperbacks, London, pp. 143-153.

March, J.G., 1991. Exploration and exploitation in organizational learning. Organization Science 2 (1), 71-87.

National Coal Board, 1957. British Coal: The Rebirth of an Industry. Hobart House, London.

Nelson, R.R., Winter, S.G., 1982. An Evolutionary Theory of Economic Change. Belknap Press, Cambridge, MA.

North, D.C., 1990. Institutions. In: Institutional Change and Economic Performance. Cambridge University Press, Cambridge.

Oliver, C., 1992. The antecedents of deinstitutionalization. Organization Studies 13 (4), 563-588.

Olson, M., 1965. The Logic of Collective Action. Harvard University Press, Cambridge, MA.

Phillips, M.E., 1994. Industry mindsets: exploring the cultures of two macroorganizational settings. Organization Science 5 (3), 384-402.

Pollard, S., 1989. Britain's Prime and Britain's Decline. The British Economy 1870-1914. Edward Arnold, London. 
Porter, M., 1980. Competitive Strategy: Techniques for Analyzing Industries and Competitors. Free Press, New York.

Ramsbottom, E.C., 1935. The course of wage rates in the United Kingdom, 1921-1934. Journal of the Royal Statistical Society 98, 639-694.

Robens, L., 1972. Ten Year Stint. Cassell, London.

Sanderson, J.B., 1961. The National Smoke Abatement Society and the Clean Air Act (1956). Political Studies 9, 236-253.

Scarrow, H.A., 1972. The impact of British domestic air pollution legislation. British Journal of Political Science 2 (3), 261-268.

Scott, P., 2006. Path dependence, fragmented property rights and the slow diffusion of high throughput technologies in inter-war British coal mining. Business History 48 (1), 20-42.

Scott, W.R., 1995. Institutions and Organizations. Sage publications, Thousand Oaks, CA.

Scott, W.R., Ruef, M., Mendel, P.J., Caronna, C.A., 2000. Institutional Change and Healthcare Organizations: From Professional Dominance to Managed Care. Chicago University Press, Chicago.

Sewell Jr., W.H., 2005. Logics of History: Social Theory and Social Transformation. University of Chicago Press, Chicago.

Sheail, J., 1997. Business and the environment: an inter-war perspective on the Federation of British Industries. Contemporary British History 11 (4), 21-41.

Shove, E., Walker, G., 2007. CAUTION! Transitions ahead: Politics, practice and sustainable transition management. Environment and Planning A 39 (4), 763-770.

Stradling, D., Thorsheim, P., 1999. The smoke of great cities: British and American efforts to control air pollution, 1860-1914. Environmental History 4 (1), 6-31.

Supple, B., 1987. The History of the British Coal Industry, Vol. 4. 1913-1946: The Political Economy of Decline. Clarendon Press, Oxford.

Supple, B., 1988. The political economy of demoralization: the state and the coalmining industry in America and Britain between the wars. The Economic History Review 41 (4), 566-591.
Taylor, 1937. The Smoke Menace, 14min., black \& white, J. Grierson, Realist Film Unit. http://www.screenonline.org.uk/film/id/1290752/

Taylor, B., 1982. Turnaround, recovery and growth: the way through the crisis. Journal of General Management 8 (2), 5-13.

Thorsheim, P., 2006. Inventing Pollution: Coal Smoke and Culture in Britain since 1800. Ohio University Press, Athens.

Tosh, J., 2010. The Pursuit of History: Aims Methods and New Directions in the Study of Modern History. Fifth edition. Pearson Education Ltd, London.

Townsend, J.F., 1976. Innovation in Coal Mining Machinery: The Anderton Shearer Loader - the Role of the NCB and the Supply Industry in Its Development. SPRU Occasional Paper Series 3.

Turner, R.L., 1989. The Politics of Industry. Christopher Helm, London.

Turnheim, B., 2012. The destabilisation of existing regimes in socio-technical transitions: Theoretical explorations and in-depth case studies of the British coal industry (1913-2010), PhD thesis, SPRU, University of Sussex.

Turnheim, B., Geels, F.W., 2012. Regime destabilisation as the flipside of energy transitions: lessons from the history of the British coal industry (1913-1997). Energy Policy 50, 35-49.

Tushman, M.L., Romanelli, E., 1985. Organizational evolution: a metamorphosis model of convergence and reorientation. In: Cummings, L.L., Staw, B.M. (Eds.), Research in Organizational Behavior, Vol. 7. JAI Press, Greenwich, CT, pp. $171-222$.

Von Tunzelmann, N., 1978. Steam power and British industrialisation to 1860 . Clarendon Press, Oxford.

Weitzel, W., Jonsson, E., 1989. Decline in organizations: a literature integration and extension. Administrative Science Quarterly 34 (1), 91-109.

Zucker, L.G., 1989. Combining institutional theory and population ecology: no legitimacy, no history. American Sociological Review 54 (4), $542-548$. 